International Journal of English Literature and Social Sciences
Vol-7, Issue-1; Jan-Feb, 2022
Journal Home Page Available: https://ijels.com/
Journal DOI: $10.22161 /$ ijels

\title{
Structural Equation Model on Subculture Perceptions of Philippine National Police Personnel
}

\author{
Johana Jamasali-Abdula, $\mathrm{PhD}^{1}$; Rinante L. Genuba, EdD ${ }^{2}$; Rogelio A. Lovina, Jr., $\mathrm{PhD}^{3}$
}

\author{
${ }^{1}$ Western Mindanao State University, Zamboanga City, Philippines \\ ${ }^{2}$ University of Mindanao, Davao City, Philippines \\ ${ }^{3}$ Jose Rizal Memorial State University, Tampilisan Campus, Zamboanga del Norte, Philippines
}

Received: 11 Dec 2021; Received in revised form: 13 Jan 2022; Accepted: 20 Jan 2022; Available online: 06 Feb 2022

(C)2022 The Author(s). Published by Infogain Publication. This is an open access article under the CC BY license

(https://creativecommons.org/licenses/by/4.0/).

\begin{abstract}
The aim of this investigation was to discover what model most appropriate fits for the perception of the police subculture of police personnel in Zamboanga City Region IX. To find out the singular and combined influence of independent variables on the perception of the police subculture. Employing correlation research design, population and sampling, and structural equation model, data were obtained from 400 police personnel from various municipalities and city Police stations in Zamboanga City. On other hand, the study established that there is an important connection in the police personnel among police stress, multifactor leadership, personality, and police subculture. A conclusive statement has been drawn based on the results of the research; police stress, leadership, personality has an important correlation in police subculture. Further, findings established that police stress, personality, and multifactor leadership is significant predictors of the police subculture. All independent variables are rejected which means that Police stress, multifactor leadership, personality are significant predictors of the police subculture. Furthermore, findings discovered that police stress, multifactor leadership, and personality established the best fit model of the study on police subculture of police personnel.
\end{abstract}

Keywords-Police Personnel, Police stress, multifactor leadership, personality, Philippine National Police station, correlation research design, Zamboanga City, Philippines

\section{INTRODUCTION}

The police counterculture study is significant because it would help to assess the subculture perception among police personnel and current ethical work conditions of police organization in Zamboanga City. Police subculture applies to the cultural perceptions that policemen retain due to their collaborative work experience. Police subculture has the aspect to destroy the reputation and integrity of a police department. Police organization adhere to police subculture is an ethical lost to police personnel himself but also a disaster to the entire criminal justice system. It is crucial when subculture occurs negatively in the police organization. Hence, to study police subculture perception is substantial.
The police counterculture study is significant because it would help to assess the subculture perception among police personnel and current ethical work conditions of police organization in Zamboanga City. Police subculture applies to the cultural perceptions that policemen retain due to their collaborative work experience. Police subculture has the aspect to destroy the reputation and integrity of a police department. Police organization adhere to police subculture is an ethical lost to police personnel himself but also a disaster to the entire criminal justice system. It is crucial when subculture occurs negatively in the police organization. Hence, to study police subculture perception is substantial.

There are several studies on subcultural perception that relate to factors that influence police personnel. Police stress is one of the factors related to 
police subculture's offensive nature (Scheingold, 1984: \& Pollock, 2007). Stressful working condition and hostile public bring norms and values that govern police behavior which makes the police subculture (Adler, Mueller, \& Laufer, 1994: Vadackumchery, 2001). On the other hand, police subculture may link with multifactor leadership. Individualized influence or charismatic individuals used coercive power to lead evil ends (Northouse, 2016). Whereas, negative personality traits are often associated with police subculture (Skolnick, 2008).

With immense challenges posed by these problems, various studies around the world have been aimed at identifying factors, drawing conclusions and providing suggestions. It is difficult to draw any specific conclusions and generalizations from the literature, because of the diverse populations, therapies, and study designs. This subject has paved a center stage position on its significant effect and influence on police officers in meeting police demands of subculture workers, with the ongoing demand for more criminological studies. Since, no research has been conducted covering all the abovementioned variables in the Philippines, especially in the City of Zamboanga, Mindanao. This present study aimed at adding evidence to a growing body of knowledge and developing a new model that aims to give a new direction on enhancing the ethical careers in law enforcement agencies.

\subsection{Research Objective}

The point of the study is to establish a causal model of perception of police subculture through police stress, multifactor leadership and policing recruitment factors. This study specifically deals with the following objectives:

1. To assess the level of police stress among Philippine National Police personnel in terms of:

\section{1 operational stress, and}

1.2 organizational stress.

2. To ascertain the level of multifactor leadership among Philippine National Police personnel in terms of:

\section{1 idealized influence,}

2.2 inspirational motivation,

2.3 intellectual stimulation, and

2.4 individualized consideration.

3. To describe the level of personality traits among Philippine National Police personnel in terms of:

\section{1extraversion,}

\section{2agreeableness,}

3.3Conscientiousness,

\section{4neuroticism, and \\ 3.5openness.}

4. To evaluate the level of perception of police subculture among Philippine National Police personnel in Zamboanga City in terms of:

4.1 crime control,

4.2 service,

4.3 traditionalism,

4.4 receptive to change,

4.5 cynism,

4.6 solidarity, and

4.7 isolation.

5. To determine the significant relationship between:

5.1 police stress and perception of police subculture;

5.2 multifactor leadership style and perception of police subculture; and

5.3 personality and perception of police subculture.

6. To determine if police stress, multifactor leadership style, personality traits

best predicts the perceptions on police subculture.

7. To determine what model best fits for the perception of police subculture

among Philippine National Police personnel.

\subsection{Hypothesis}

The following hypotheses were tested at a significance level of 0.05 :

1. There is no significant relationship between:

1.1 police stress and perception of police subculture;

1.2 multifactor leadership style and perception of police subculture; and

1.3 personality and perception of police subculture.

2. There is no variable that can best predict perception of police subculture among Philippine National Police Personnel.

3. There is no model that best fits for the perception of subculture among Philippine National Police Personnel. 


\section{REVIEW OF RELATED LITERATURE}

This section presented different views from related studies pertaining to the dependent variable police subculture perception which consists of crime control, service, cynism, receptive to change, traditionalism, solidarity and isolation (Chen, 2016). On the other hand, the independent variable police stress has two indicators as identified by McCreary and Thompson (2006) namely: operational and organizational stress. The independent variable multifactor leadership has four indicators namely: idealized influence, inspirational motivation, intellectual stimulation, individualized consideration (Hughes, 2014). Another independent variable is personality trait in which according to Goldberg (1993) has five indicators namely: extraversion, agreeableness, conscientiousness, neuroticism and openness.

\subsection{Police Stress}

Many investigators wanted to present a perfect and final list of categories of stress factors in the police profession. In everyday life, but also in professional life, the stress issue is becoming increasingly relevant. Stress seriously affects police officers ' physical and mental health, their social lives, and the very organization, which hires them. Different people point to different sources of stress. Stress interferes with the standard flow at work hours. Police stress is an issue that is relevant to the professional life of police personnel. Stress greatly affect the police personnel physical and mental health, their social life and the police department which they are employed suffers damages. There are researcher's points put to different sources of stress. Police work is considered to be one of the most stressful job. As police officers, they are susceptible to trauma and stress (Anshel, 2000).

\subsection{Multifactor Leadership}

The term leadership refers to having an impact on the performance, efficiency, employee satisfaction, workplace engagement, pressure and endurance of employees (Allen, 2012; Britt et al., 2004; Cunniff, 2013; Dirks \& Ferrin, 2002; \& Everly, 2012). On other hand, the concept has often been recognized as the one key factor for institutional failure (Bass \& Bass, 2009). In addition to leadership, it is important as to direct staff such as the police that could have favorable results and promote the workplace culture of the police that the police managers have to accept. Leadership is noted to be successful, it can create an environment of confidence, development, and progress that can boost performance (Bates et al., (2010).

\subsection{Personality Traits}

Many years of study, showed that there has been an increased interest in understanding the personality characteristics of individuals drawn to law enforcement (Aamodt, Brewster, \& Raynes, 1998; Aamodt \& Kimbrough, 1985; Biggam \& Power, 1996; Fitch, 2014; Hogan 1971; Hogan \& Kartines, 1975). On other hand, individual personality is composed of several factors, including character traits, states values and attitudes, as well as cognitive and behavioural styles( Cohen \& Swerdlik, 1999). The assessment of personality is important in law enforcement because simply put, not all applicants are suitable for the police profession (Fitch, 2014). The American Psychological Association (APA, 2017) describes attitude as gender differences in habits of thought, thinking, and action feature.

\subsection{Police Subculture}

Police subculture is a mixture of common cultural standards, objectives, job preferences, attitudes and professional frameworks which is somewhat distinct from the mix possessed by the rest of society, while police share the prevailing values of a broader culture in most significant ways. Like most subcultures, the subculture of the police ooficersis described by clanness, confidentiality and alienation from anyone not in the party ((Dempsey, Forst \& Carter, 2019; \& Crank, \& Caldero, 2000)). On other hand, Crank and Caldero (2000); Sherman (1982) stated that police personnel with high subcultures supports a distinctive system of values, with particular emphasis on integrity, courage and freedom. Furthermore, in certain cases the abuse of power and the infringement of the fundamental rights (Fitch, 2014: Kappeler, Sluder, and Alpert, 1998; Skolnick \& Fyfe, 1993).

\subsection{Correlations between Measures}

There are researches have suggested relationship between police stress and the police subculture. Police stress is one of the factor that links to the extreme nature of the police subculture (Scheingold, 1984; \& Pollock, 2007). This belief necessitate that danger, unusual shift work, social stigma and unpleasant experience in police work is full of considerable stress which encourages different behaviour. Further, police stress develop a sense of feeling of distinct and separate from everyone in the community. According to the study, police subculture is influence by untoward incident, unfair judgment, abnormal working hours and constant change in organizational policies.

Behavioural reaction or physical changes in the body are common response to police stress. A significant consequence on every occupation and police officer that police stress induced (Ellison, 2004: \& Jaramillo, Nixon \& Sams, 2005). The failure of hundred of millions of days of work due to work and disease truancy, or even suicidal ideation, are leads of police pressure (Treven \& Potocan, 2005). Police stress is influencing police subculture in that 
sense. Subculture in the police is the result of exhausting workplace conditions plus daily engagement with an often aggressive public. The subculture of police brought by pressure has a set of norms and standards which govern police conduct, (Adler, Mueller, \& Laufer, 1994; \& Vadackumchery, 2001).

Multifactor leadership (transformation leadership) is not successful when police supervisors enable subordinates to take decisions; however, subordinates ' encouragement is peculiar with the bureaucratic police system (Bowie, 2000). Such a management style is challenging within a society that is so deeply embedded in a military type of structure where it is required across the leadership to obey the rules and policies. There is possible partnership between multifactor leadership (transformation leadership) and police subculture. The importance of police subculture on the officer takes into account the influences of the circumstance which are the implicit principles, standards (in militaristic organization), and methods in doing something that affect the police personnel ' day-to-day actions and decisions (Schein, 1992).

Knowing how management of multifactor (transformational leadership) emotionally affect subordinates and to response of superiors (Bailey \& Axelrod, 2001). For example of individualized influence or charismatic individuals who used coercive power to lead to evil ends (Northouse, 2016). Coercive leadership in its threats does lowering the self-esteem of subordinates who feel stressed, angry, subjugates and victimized by the coercive leaders. This idea is supported by Atwater, Camobreco, Dionne, Avolio and Lau (1997) found that leader non contingent punishment elicited negative emotional reactions from followers. The feeling of stressed, angry and negative emotional reaction leads to police subculture. Knowing how management of multifactor (transformational leadership) emotionally affect subordinates and to response of superiors. This relates to police officers who have felt ineffective governance and insufficient supervisory support, increased feelings of distrust and scepticism towards supervisors and managers, and reduced results.

When examining the relationship of multifactor leadership (transformation management) and police subculture, transformation management imposes a responsibility on individuals and organizations to be informed of how they are affected and in which ways they are being requested to go (Northouse, 2016). The constant demand to attain the vision for the future and constantly take pride in the accomplishments of the organizations can lead to demotivation and exhaustion in other subordinates (Thompson, 2019).

When researching multifactor leadership with regard to police subculture, it directs police officers to take the correct decisions by fulfilling their subordinates ' ethical guidance (Mastrofski, 2004). Failure to enforce these values will, however, result fellow employees to replicate the corrupt practices of their chief, leading to poor decision making. There are issues associated with encouraging subordinates to enforce the law, such as ignoring, losing, or actually not adhering to the values of their leader; risk becomes possible when subordinates are granted expanded control. Multifactor leadership and policing subculture are associated together in this philosophy.

Leadership can contribute to stress Individualized and self-aggrandising leadership can cause more tension among followers which leads to hurried acts and incorrect decisions. Instead of alleviating stressful problems that lead to bad feelings for subordinates, such leadership can create unnecessary acts and leads to poorer job performance. Combative leaders use their power to force their subordinates, and thus cause serious problems. Herzberg (1966) Identify that the most frustrating part of the job situation can be the numerous subordinates, direct superiors. Oppressive police supervisors are the most commonly identified as a major source of job stress. Bass (1960) notes out that such leader are based on their ability to force their followers into transactions or trade.

Police personality is attributed to the personality tendency present before the police recruits are inducted into the subculture of police. Distinct personality traits contribute to a career in the police profession and allow police to fit easily into the subculture of the police (Conti, 2010; Rokeach et al., 1971). On other hand, policing subculture often associates negative personality characteristics (Skolnick 2008). Police subculture fully describes an individual police police officer or what it means to be a police officer by the characteristics that police officers display. According to Skolnick (2008) such features include fear and distrust, apprehension, mistrust of others, all qualities that police critics attribute to them and relate to them. The proof in this proposition is that there is a link between personality characteristics and the police subculture.

Personality traits have long been an interest in understanding how a person is attracted to the police force's work (Aamodt, Brewster, \& Raynes, 1998; Aamodt \& Kimbrough, 1985; Biggam \& Power, 1996; Hennessy, 1999:Hogan 1971; Hogan \& Kurtines, 1975; \& Lester, Bobcock, Cassisi, Genz, \& Butler, 1980). There are several 
variables consisting of an individual's personality which includes character traits, state beliefs and values, and behavioral types (Cohen \& Swerlik, 1999). Evaluation of personality was relevant for police officers since not all police candidates are fit for the career (Fitch, 2014).

In contrast to personality assessment for the individual worthy to be police officer and once joined the organization susceptibility to police subculture is definite. Some researchers call police characteristics as an indication of police subculture common to many other police officers. It is believed that temperament contains characteristics such as authoritarianism, distrust, aggression, hostility, populism, and pessimism; (Dempsey, Forst, Carter, 2019) police skepticism, for instance, can be a reaction to their prolonged exposure to lies and excuses told by people who did not want to be held responsible; shell police's resilience designed to protect themselves from ' bad experiences ' (Van Maanen, 1978).

In the study of Worden and Catlin (2002) disclosed that a small percentage of police officers are accountable for large numbers of incidents involving power. Police officers suffering from lack of compassion, avoidant personality disorder, anxiety, and skepticism, as well as inability to learn from their mistakes or learn from experience are individuals classified as closely associated with police subculture (Fitch, 2014). On other hand, the actions of police officers and the subculture of policing are also intertwined. This is the unexpressed principles, traditions, and ways of thinking that affect the day-to-day actions and decisions of law enforcement officers while assessing situational considerations, behavior of officers and subculture of police are relevant (Schein, 1992).

The related literature and studies provided most needed knowledge and background for the subject under study specifically on the relationship among variables and how these variables and their indicators affect one another. The knowledge culled out from renowned scholars contributed with much understanding in the formulation of the theoretical framework and in the development of the questionnaire.

\subsection{Conceptual Framework}

The hypothesized models were composed of two types of latent constructs, namely exogenous and endogenous variables. The exogenous variables of this study were police stress, multifactor leadership and personality. On the other hand, the endogenous variable is police subculture perception. Because endogenous factors were not empirically verified, it implies that they are not directly observable with this, the numerous calculations or factors observed associate each latent construct. So, one of the ultimate goals of this study is the degree of the regression paths from the latent variable to the observed variables.

The latent police stress has two indicators namely operational and organizational stress. Operational stress describes the police work underlying in the job, such as work extra hours, trial extra hours, legal work, and dangers associated with the work; Workplace conflict refers to working conditions, human resources practices and legislation (McCreary \& Thompson, 2006). Nonetheless, organizational stress is the product of employment conditions, potential influence on the activities and occupational prejudice (Carter, Dempsey \& Forst, 2019).

The latent multifactor leadership has four variables namely, idealized influence, inspirational motivation, intellectual stimulation, and individualized consideration. Idealized influence refers to subordinates trusting, preserving their confidence and loyalty; showing commitment; giving members a common vision and a strong sense of purpose to subordinates (Northouse, 2016). Inspirational motivation refers to the use of adequate meanings and photographs to help others focus on their work and try to make others feel that their work is important; Social interaction refers to encouraging others to look creatively at old issues in novel ways, creating a culture that is considerate of apparently conservative positions, and encourage police officers to question their own and corporate beliefs and practice; Individualized concern relates to showing interest in other people's wellbeing; assigning tasks individually; and paying attention to those who seem much less interested in the community (Bass \& Avolio, 1992).

The latent personality has four observed variables namely, extraversion, agreeableness, conscientiousness, neuroticism and openness. Extraversion refers to the personality trait of seeking fulfilment from sources outside the self or in community, includes the traits of energetic, talkative, and assertive, Agreeableness refers to the behaviour that suit others, friendly, cooperative, and compassionate, kind, affectionate, sympathetic and willing to help those in need (Habashi, Graziano, \& Hoover, 2016) (Burger, 2019). Conscientiousness refers to of being honest and hardworking, reliable, organized, methodical, and thorough. Neuroticism refers to emotional stability and degree of negative emotions, being moody and tense; Openness refers to learning new experience and intellectual pursuits, being insightful and imaginative and having a wide variety of interests (Goldberg, 1993) and this dimensions refers to as intellect, although it is certainly not the same as intelligence (Burger, 2019). 
Police subculture consist of seven indicators namely, consist of the crime control, service, traditionalism, receptive to change, cynism, solidarity, isolation. Crime control refers to a strong preference for the role of felony-fighting; a feeling of purpose and a desire to use abusive police tactics; operation refers to community police systems for citizens. Conservatism refers to ' political positions which are operationally compelled to take and whose politics is educationally inclined to think and hold; Sympathetic to transition refers to accomplished or serious changes from conventional policing style to provider-oriented police style, including neighbourhood police. Cynicism refers to attitudes of law enforcement officers. This includes general disdain and lack of hope for people and the criminal justice system. Unity refers to a way of coping to protect officers from the inherent hazards and complexities of police work. Social alienation and loneliness refers to a psychological one and A physical state that makes connections and interaction with members of another group challenging for leaders of one cultural group (Chen, 2016).

This study introduced five alternative models as shown in Figures 1 to 5 in the preceding pages. The model framework was decomposed into two submodels: a measurement model, and a causal model. The measurement model define relations between the observed and unobserved variables. In contrast, the causal model defines relations among unobserved variables. Furthermore, the five hypothesized structure models displayed potential causal dependencies between the independent and dependent variables.

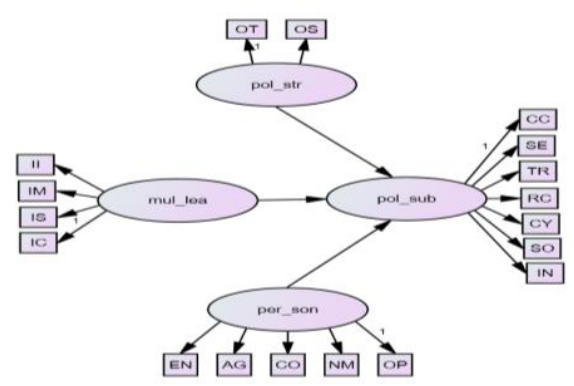

Fig.1. Conceptual Model of the Study

\section{METHODS METHOD}

Presented in this chapter a detailed description of the methodology used in this study. The main components of this chapter research design, research locale, population and sample research instrument, data collection, statistical tools and ethical consideration.

\subsection{Research Design}

In this research study the systematic nonexperimental research approach was used. The researcher used the structural equation model (SEM) for this study for some reasons.

First, It used a descriptive-correlative research method in which this test is a calculation of component correlations of different measurement rates. In addition, Szapkiw (2012) notes that descriptive-correlative research offered an overview of the specific situation of the population defined and explored the degree to which two or more variables respond to each other.

Secondly, this research used the concept of the Structural Equation (SEM). As cited by Lomax \& Li (2013) and Genuba, Gempes, and Panes (2017) have found out in order to test theoretical relationships between latent variables. This approach integrates variable analysis with pathway analysis. Models can vary from basic to complex in nature, because they can include any number of factors of any form (i.e. independent and/or dependent variables). The integration of variable analysis in structural equation modelling enables the investigator to use various measurements of each factor rather than a measurable statistic, thus enabling better measurement conditions (i.e., reliability and validity) than with a single measure.

Structural equation modelling (SEM) uses different types of models to explain correlations between observed variables, with the same basic objective of providing a quantitative test of a theoretical framework predicted by the researcher, as noted by Schumacker and Lomax (2010). More specifically, in SEM, various conceptual models can be tested to theorize how structures are specified by sets of variables and how these frameworks are interrelated. Research method's suitability relates to design that offers the "best fit" for answering scientific questions (Maxwell, 2005).

This technique was used to calculate the view of police subculture relationships among Philippine National Police personnel in Zamboanga City, among police stress, multifactor leadership, and personality traits.

\subsection{Population and Sample}

Since this study aimed to assess the subculture perception among Philippine National Police personnel, the researcher utilized the Slovin's equation in determining the random of population and set by simply sampling respondents at random. Determining the 400 respondents appropriate for modeling structural equations; The Slovin formula is where an investigator chooses a group from the population based on their experience of the topic since the 
respondents are chosen according to the study's requirements (Stephanie, 2015).

The respondents of the study included the commissioned and non-commissioned police personnel of Zamboanga City Police Office because they were the ones who may provide useful information to test the hypothesis of this study. Excluded groups were the non-uniformed personnel of the same responding agency because this study focuses on the subculture perceptions of police personnel of Zamboanga City Police Office.

The respondents withdrawn from the research study if he/she commits falsification, plagiarism and other moral offenses or the respondents have health and special needs. A researcher may at any time withdrawn from the survey if he / she feels upset or uncomfortable. If that is the case, the police officer will tell the investigator he / she wanted to withdraw. A respondent can also provide reason(s) for the investigator to leave but is not obliged to give his reason.

\subsection{Research Instrument}

This research modified questionnaire obtained from Internet sources. The questionnaire has been updated to contain only certain elements that are applicable to the study. The proposal was first shown for comments and suggestions to the researcher's adviser, after which experts were asked to verify the said survey. After the experts had been checked, the questionnaire's usability was evaluated by pilot tests with Cronbach Alpha of.877. Gliem (2003) expressed this, Cronbach's alpha accuracy coefficient usually varies from 0 to 1 . There is in general no lower limit to the exponent, though. The higher the alpha coefficient of Cronbach is to 1.0 the greater the internal consistency of the objects in the system. On the other hand, The following finger rules were given by George and Mallery (2003): Cronbach's Alpha > .9 - Excellent; Cronbach's Alpha > .8 - Good; Cronbach's Alpha > 7 Acceptable; Cronbach's Alpha > .6 - Contestable; Cronbach's Alpha > .5 - Poor; and Cronbach's Alpha < .5 - Acceptable.

Thus, increasing the alpha value depends a great deal on the number of items in the system. It should be remembered that this has limited returns. It is also worth noting that the. 8 alpha is actually a reasonable target. While using Likert-type scales, it is essential to calculate and reveal the Cronbach alpha coefficient for the accuracy of logical consistency for any scales or subscales that may be used. Then the analysis of data must use such combined measures or subscales and not individual items. Cronbach's alpha does provide reliability figures for individual items.

This questionnaire was composed of factors such as: perceptions of police subculture, polices tress, leadership of multifactor and personality. There were four instruments used in this study namely: perception of police subculture survey, police stress survey, multifactor leadership questionnaire, and personality test.

Perception of Police Subculture (PPS) survey. Based on the dissertation research of Chen (2016), this scale was designed to understand better the extend of police officers adhere to police subculture. PPS consists of 35 items divided into seven (7) subscale namely, crime control, service, traditionalism, receptive to change, cynism, solidarity, isolation. The scoring guide in the police subculture perception analysis of the responses was categorized into five levels. The scale is as follows:

$\begin{array}{cc}\begin{array}{c}\text { Range } \\ \text { Measures }\end{array} & \begin{array}{c}\text { Descriptive } \\ \text { Level }\end{array} \\ 4.20-5.00 & \text { Very High } \\ 3.40-4.19 & \text { High }\end{array}$

$2.60-3.39 \quad$ Moderate

\section{Interpretation}

This means that police subculture among police personnel is always manifested.

This means that police subculture among police personnel is oftentimes manifested.

This means that police subculture among police personnel is sometimes manifested.

This means that police subculture among police personnel is seldom manifested. 

$1.00-1.79$
Very Low
This means that police subculture among police personnel is not manifested.

Police Stress Survey (PSS). Police Stress Survey developed by McCreary and Thompson (2006). The (PSS) is consist of 20 items divided into two subscales: operational and organizational Scale. In evaluating the police stress among police officers, the scale below was used.

Range of Means Descriptive Equivalent

$4.20-5.00$

$3.40-4.19$

$2.60-3.39$

$1.80-2.59$
Very High

High

Moderate

Low

Very Low

\section{Interpretation}

This means that police stress among police personnel is always manifested.

This means that police stress among police personnel is oftentimes manifested.

This means that police stress among police personnel is sometimes manifested.

This means that police stress among police personnel is seldom manifested.

This means that police stress among police personnel is never manifested.

Multifactor Leadership Survey (MLS). Multifactor Leadership Survey related to transformational leadership was develop by Bass and Avolio (1992). This MLS instrument is composed of twelve items divided into four subscales: idealized influence, inspirational motivation, intellectual stimulation and individualized consideration. This scale is to determine the multifactor leadership among police managers towards police members. In evaluating the multifactor leadership style, the scale below is used:.

$\begin{array}{lr}\begin{array}{c}\text { Range } \\ \text { Measures }\end{array} & \begin{array}{c}\text { Descriptive } \\ \text { Level }\end{array} \\ 4.20-5.00 & \text { Very High } \\ 3.40-4.19 & \text { High } \\ 2.60-3.39 & \text { Moderate }\end{array}$

$1.80-2.59 \quad$ Low

\section{Interpretation}

This indicates that multifactor leadership among police personnel is always manifested.

This indicates that multifactor leadership among the police personnel is oftentimes manifested.

This indicates that multifactor leadership among police personnel is sometimes manifested.

This indicates that multifactor leadership among police personnel is seldom manifested. 


$$
1.00-1.79 \quad \text { Very Low }
$$

This indicates that multifactor leadership among police personnel is never manifested.

Personality Test (PT) was developed by Goldberg (1993). This instrument consists of 25 parts, split into five subscales namely, extraversion, agreeableness, conscientiousness, neuroticism and openness. This scale was determined to what degree of personality is structure. In evaluating the personality, the scale below is used:

\begin{tabular}{|c|c|c|}
\hline $\begin{array}{c}\text { Range } \\
\text { Measures }\end{array}$ & $\begin{array}{l}\text { Descriptive } \\
\text { Level }\end{array}$ & Interpretation \\
\hline $4.20-5.00$ & Very High & $\begin{array}{l}\text { This means that personality among police personnel is } \\
\text { always manifested. }\end{array}$ \\
\hline $3.40-4.19$ & High & $\begin{array}{l}\text { This means that personality among police personnel } \\
\text { is oftentimes manifested. }\end{array}$ \\
\hline $2.60-3.39$ & Moderate & $\begin{array}{l}\text { This means that personality among police personnel } \\
\text { is sometimes manifested. }\end{array}$ \\
\hline $1.80-2.59$ & Low & $\begin{array}{l}\text { This means that personality among police personnel is } \\
\text { seldom manifested. }\end{array}$ \\
\hline $1.00-1.79$ & Very Low & $\begin{array}{l}\text { This means that personality among police personnel is } \\
\text { never manifested. }\end{array}$ \\
\hline
\end{tabular}

Goodness of Fit Statistics for the Alternative Model thru Analysis of Moment Structure (AMOS). All the values of the given indices must fall with each criterion in order to identify the best fit model.

Chi Square/Degree of Freedom (CMIN/DF)

$\mathrm{P}$ Value

Normative Fit Index(NFI)

Comparative Fit Index (CFI)

Goodness of Fit Index (GFI)

Tucker Lewis Index

Root Mean Square Error of Approximation (RMSEA)

$\mathrm{P}$ close

\subsection{Data Collection}

The data gathered following the hereunder procedures: the researcher secured the Police City Director's correct name thru office visit and inquiry from their information desk officer. The investigator referred the
$0<$ value $>2$

$$
\begin{aligned}
& >0.05 \\
& >0.95 \\
& >0.95 \\
& >0.95 \\
& <0.05 \\
& <0.50
\end{aligned}
$$

letter duly noted by the Dean of Professional Schools to the City Commander of Zamboanga City Police Office, asking permission to undertake a study among Philippine National Police workers in Zamboanga City; For potential clarification and feedback, the preliminary version of the conducted questionnaire was referred to the research 
advisor; the said questionnaire was subsequently referred for reliability and validation to the panel of experts. The investigator had an actual contact with the city director's office to directly notify about the purpose of the study and clarified the survey questionnaire, and at the same time asked permission to engage in the study for the schedule and availability of police officers.

Upon approval of time and date, the researcher introduced herself and read the consent forms and importance of their participation. The participation was voluntary and not mandatory that they could withdraw any time. The investigator honestly advised the respondents and handed out the research instrument to the respondents to ensure that the questionnaire was retrieved by one hundred (100 per cent) per cent. The researcher then thanked the respondents for their time, and answered the questionnaire on a volunteer basis. The research was conducted during the second semester of the 2018-2019 school year. The certificate of attendance was signed by the City Director / Police Supervisor and it was ensured that the researcher honestly collected the data from the respondents. The data collected by the investigator was compiled, analyzed and interpreted for the purpose of the study.

\subsection{Statistical Tools}

\section{Statistical Tools}

The following statistical tools were used in the computation of data and testing the hypotheses at alpha 0.05 level of significance.

Mean. This was used to determine the level of between police stress, multifactor leadership, personality, and police subculture perception.

Pearson(r). This was applied to determine the interrelationship between police stress, Multifactor leadership, personality, and Police subculture perception.
Multiple Regression Analysis. This was employed to determine the significant influence between police stress, Multifactor leadership, personality, and police subculture perception.

Structural Equation Modeling (SEM). This was used to explore the best fit model. Factor analysis was carried out in testing the latent variables.

\section{RESULTS AND DISCUSSIONS}

This chapter includes the presentation of the data gathered and the comprehensive discussion, interpretation and implication of the findings of the study.

\subsection{Level of Police Stress among Philippine National Police Personnel}

Table 1 presented the level of police stress among Philippine National Police personnel which is arranged from highest (3.52) to lowest 3.51. It is measured by two indicators namely: operational stress and organizational stress. Each of these describes a specific way for the subculture perceptions among police personnel. The two indicators of police stress generated a total average rating of 3.51 which is described as high. This means that the police stress in terms of organizational stress and operational stress were oftentimes manifested by Philippine National Personnel police personnel. In the same way, the overall mean of organizational stress was defined as high with the registered mean of 3.51.

Table 1; Level of Police Stress among Philippine National Police Personnel

\begin{tabular}{lccc}
\hline Indicator & SD & Mean & Descriptive Level \\
\hline Operational Stress & 0.65 & 3.52 & High \\
Organizational Stress & 0.58 & 3.51 & High \\
Overall & $\mathbf{0 . 5 5}$ & $\mathbf{3 . 5 1}$ & High \\
\hline
\end{tabular}

\subsection{Level of Multifactor Leadership among Philippine National Police Personnel}

Table 2 presents the list of the items in the four indicators of multifactor leadership. This variable has four indicators namely, idealized influence, inspirational motivation, intellectual stimulation and individualized consideration. The four indicators of the multifactor leadership were arranged from highest to lowest and obtained overall mean rating of 3.93 which is described as high. This means that the multifactor leadership among police personnel is oftentimes manifested. The results showed that idealized influence attained the highest means rating among the four indicators of multifactor leadership 
with overall mean of 4.07 which is described as high. In terms of inspirational motivation obtained the overall mean rating of 3.91 which is described as high. Meanwhile, the overall mean of intellectual stimulation obtained a mean rating of 3.76 which is described also as high. In the aspect of individualized consideration attained the mean score of 3.99 which is described as high.

Table 2 Level of Multifactor Leadership among Philippine National Police Personnel

\begin{tabular}{lccc}
\hline Indicator & SD & Mean & Descriptive Level \\
\hline Idealized Influence & 0.62 & 4.07 & High \\
Individualized Consideration & 0.64 & 3.99 & High \\
Inspirational Motivation & 0.60 & 3.91 & High \\
Intellectual Stimulation & 0.67 & 3.76 & High \\
Overall & $\mathbf{0 . 5 3}$ & $\mathbf{3 . 9 3}$ & High \\
\hline
\end{tabular}

\subsection{Level of Personality among Philippine National Police Personnel}

Table 3 presents the level of personality among Philippine National police personnel and were arranged from highest (3.59) to lowest (2.90) which is measured by five indicators namely: extraversion, agreeableness, conscientiousness, neuroticism, and openness. These indicators determined the personality and traits among police personnel.
The five indicators of personality obtained an over-all mean of 3.33. which is described as moderate.

This means that personality among police personnel was evident but sometimes manifested. The level of personality in terms of extraversion obtained with a total average rating of 3.59 which is defined as high. This means that the personality among police personnel in terms of extraversion is oftentimes manifested.

Table 3 Level of Personality among Philippine National Police Personnel

\begin{tabular}{lccc}
\hline Indicator & SD & Mean & Descriptive Level \\
\hline Extraversion & 0.62 & 3.59 & High \\
Conscientiousness & 0.50 & 3.59 & High \\
Openness & 0.50 & 3.38 & High \\
Agreeableness & 0.64 & 3.19 & Moderate \\
Neuroticism & 0.72 & 2.90 & Moderate \\
Overall & $\mathbf{0 . 4 1}$ & $\mathbf{3 . 3 3}$ & Moderate \\
\hline
\end{tabular}

Meanwhile, the level of personality in terms of agreeableness was described as moderate with a total average rating of 3.19 . The average rating of 3.19 which is described as moderate indicated that the personality among police personnel in terms of agreeableness was considerable or sometimes manifested. In the same way, the level of personality in terms of conscientiousness was high with an overall mean rating of 3.59. This means that conscientiousness was often times manifested. The other indicator neuroticism was rated moderate with an overall mean rating of 2.90 were rated moderate. This meant that the personality in terms of neuroticism was sometimes manifested. However, the level of personality in terms of openness was moderate with an overall mean rating of 3.38. This implies that personality in terms of openness is sometimes manifested. This indicates further that openness is considerable importance in personality of police personnel. 
Table 4 Level of Police Subculture among Philippine National Police Personnel

\begin{tabular}{llll}
\hline Indicator & SD & Mean & Descriptive Level \\
\hline Solidarity & 0.63 & 4.06 & High \\
Service & 0.58 & 3.86 & High \\
Traditionalism & 0.55 & 3.78 & High \\
Receptive to Change & 0.52 & 3.59 & High \\
Isolation & 0.61 & 3.56 & High \\
Crime Control & 0.65 & 3.55 & High \\
Cynism & 0.65 & 3.33 & Moderate \\
Overall & $\mathbf{0 . 4 2}$ & $\mathbf{3 . 6 8}$ & High \\
\hline
\end{tabular}

\subsection{Level of Police Subculture among Philippine National Police Personnel}

Table 4 presents the list of items in the seven indicators of the police subculture among Philippine National Police personnel and were arranged from highest (4.06) to lowest (3.33). These indicators include crime control, service, traditionalism, receptive to change cynism, solidarity and isolation. The seven indicators of police subculture obtained overall mean rating of 3.68 which is described as high. This implies that police personnel have high perceptions of police subculture and often times manifested among police personnel.

In the aspect of crime control, the overall mean was 3.55 or high. This meant police subculture in terms of crime control is often times manifested. The overall mean of 3.55 or high indicates that the police subculture in crime control was substantial.
In terms of service, the overall mean rating was 3.86 described as high. This meant that the police subculture in terms of service is oftentimes manifested. In the aspects of traditionalism, the overall mean rating was 3.78 described as high. This meant that traditionalism was evident most of the time or frequently exhibit. Meanwhile, the overall mean of receptive to change has a mean of 3.59 or high. This meant that receptive to change of police personnel was manifested often times. The overall police subculture in terms of cynism had a moderate level with a mean of 3.33. This meant that cynism was evident but not all the time or sometimes manifested.

Another indicator showing high level was solidarity with an overall mean of 4.06. This meant that these items are often times manifested indicating further that the police personnel in terms of solidarity was great. The other indicator isolation was rated high with an overall mean of 3.56 This indicates further that isolation is of great importance in police subculture and oftentimes manifested.

Table 5.1 Significance on the Relationship between Police Stress and Perceptions of Police Subculture among Philippine National Police Personnel

\begin{tabular}{|c|c|c|c|c|c|c|c|c|}
\hline \multirow{2}{*}{$\begin{array}{l}\text { Police } \\
\text { Stress }\end{array}$} & \multicolumn{8}{|c|}{ Perception of Police Subculture } \\
\hline & $C C$ & $S E$ & $T R$ & $R C$ & $C Y$ & SO & $I N$ & Overall \\
\hline \multirow{2}{*}{$O S$} & $.264 * *$ & $.262 * *$ & $.248 * *$ & $.283 * *$ & $.333 * *$ & $.213 * *$ & $.252 * *$ & $.372 * *$ \\
\hline & $(.000)$ & $(.000)$ & $(.000)$ & $(.000)$ & $(.000)$ & $(.000)$ & $(.000)$ & $(.000)$ \\
\hline \multirow{2}{*}{$O T$} & $.348 * *$ & $.303^{* *}$ & $.339 * *$ & $.366^{* *}$ & $.351 * *$ & $.274 * *$ & $.244 * *$ & $.445 * *$ \\
\hline & $(.000)$ & $(.000)$ & $(.000)$ & $(.000)$ & $(.000)$ & $(.000)$ & $(.000)$ & $(.000)$ \\
\hline \multirow{2}{*}{ Overall } & $.340 * *$ & $.315 * *$ & $.326 * *$ & $.361 * *$ & $.382 * *$ & $.271 * *$ & $.278 * *$ & $.455 * *$ \\
\hline & $(.000)$ & $(.000)$ & $(.000)$ & $(.000)$ & $(.000)$ & $(.000)$ & $(.000)$ & $(.000)$ \\
\hline
\end{tabular}


Legend:

$$
\begin{array}{ll}
\text { OS }=\text { Operational Stress } & R C=\text { Receptive to } \text { Change } \\
O T=\text { Organizational Stress } & C Y=\text { Cynism } \\
C C=\text { Crime Control } & S O=\text { Solidarity } \\
S E=\text { Service } & I N=\text { Isolation } \\
T R=\text { Traditionalism } &
\end{array}
$$

4.5 Significance on the Relationship between Police Stress and Perception of Police Subculture among Philippine National Police Personnel

The data in table 5.1 shows the correlation between the police stress and police subculture perceptions among Philippine National Police personnel. It can be perceived from the results that there might be a notable positive strong association among police stress and police subculture perceptions as reflected in the table, the P-value that was less than 0.05 and correlation coefficient, $\mathrm{r}=$ 0.455 . The null hypothesis, that there is no significant relationship between police stress and police subculture perception was therefore rejected. This meant that police

\begin{tabular}{|c|c|c|c|c|c|c|c|c|}
\hline \multirow{2}{*}{$\begin{array}{l}\text { Multifactor } \\
\text { Leadership }\end{array}$} & \multicolumn{8}{|c|}{ Perception of Police Subculture } \\
\hline & $C C$ & SE & $T R$ & $R C$ & $C Y$ & SO & IN & Overall \\
\hline \multirow{2}{*}{ II } & $.325 * *$ & $.337 * *$ & $.358 * *$ & $.357 * *$ & $.208 * *$ & $.390 * *$ & $.271 * *$ & $.449 * *$ \\
\hline & $(.000)$ & $(.000)$ & $(.000)$ & $(.000)$ & $(.000)$ & $(.000)$ & $(.000)$ & $(.000)$ \\
\hline \multirow{2}{*}{ IM } & $.291 * *$ & $.316 * *$ & $.324 * *$ & $.411 * *$ & $.200 * *$ & $.388 * *$ & $.338 * *$ & $.453 * *$ \\
\hline & $(.000)$ & $(.000)$ & $(.000)$ & $(.000)$ & $(.000)$ & $(.000)$ & $(.000)$ & $(.000)$ \\
\hline \multirow{2}{*}{ IS } & $.319 * *$ & $.354 * *$ & $.302 * *$ & $.406 * *$ & $.280 * *$ & $.300 * *$ & $.340 * *$ & $.460 * *$ \\
\hline & $(.000)$ & $(.000)$ & $(.000)$ & $(.000)$ & $(.000)$ & $(.000)$ & $(.000)$ & $(.000)$ \\
\hline \multirow{2}{*}{$I C$} & $.362 * *$ & $.351 * *$ & $.353 * *$ & $.385 * *$ & $.212 * *$ & $.340 * *$ & $.371 * *$ & $.475 * *$ \\
\hline & $(.000)$ & $(.000)$ & $(.000)$ & $(.000)$ & $(.000)$ & $(.000)$ & $(.000)$ & $(.000)$ \\
\hline \multirow{2}{*}{ Overall } & $.387 * *$ & $.406^{* * *}$ & $.398 * *$ & $.465 * *$ & $.269 * *$ & $.421 * *$ & $.394 * *$ & $.548 * *$ \\
\hline & $(.000)$ & $(.000)$ & $(.000)$ & $(.000)$ & $(.000)$ & $(.000)$ & $(.000)$ & $(.000)$ \\
\hline
\end{tabular}
stress was strongly related to perception of police subculture among Philippine National Police personnel.

Table 5.2 Significance on the Relationship between Multifactor Leadership and Perception of Police Subculture among Philippine National Police Personnel

Legend:

$$
\begin{aligned}
& I I=\text { Idealized Influence } \\
& I M=\text { Inspirational Motivation } \\
& I S=\text { Intellectual Stimulation } \\
& I C=\text { Individualized Consideration } \\
& C C=\text { Crime Control }
\end{aligned}
$$

$$
\begin{aligned}
& T R=\text { Traditionalism } \\
& R C=\text { Receptive to } \text { Change } \\
& C Y=\text { Cynism } \\
& S O=\text { Solidarity } \\
& I N=\text { Isolation }
\end{aligned}
$$

4.6 Significance on the Relationship between Multifactor Leadership and Perception of Police Subculture among Philippine National Police Personnel

Similarly, the data in table 5.2 shows the relationship between Multifactor leadership style and perception of police subculture among Philippine National Police personnel. It is established to be very important with registered P-value of less than 0.05 , and $r=0.548$. This implies that the multifactor leadership style greatly concerned with perception of police subculture.

Thus, the null hypothesis was rejected. The findings also suggested that to have a positive leadership of police personnel, the police personnel should have a 
deeper manifestation of the four multifactor leadership namely: idealized influence, inspirational motivation, intellectual stimulation, individualized consideration. Likewise, it can be observed that all four indicators of multifactor leadership: idealized influence, inspirational motivation, intellectual stimulation, individualized consideration showed a significant relationship to crime control, service, traditionalism, receptive to change, cynism, solidarity, isolation as their individual P-value were less than 0.05 .

Table 5.3 Significance on the Relationship between Personality and Perceptions of Police Subculture among Philippine National Police Personnel

\begin{tabular}{|c|c|c|c|c|c|c|c|c|}
\hline \multirow{2}{*}{ Personality } & \multicolumn{8}{|c|}{ Perception of Police Subculture } \\
\hline & $C C$ & $S E$ & $T R$ & $R C$ & $C Y$ & SO & $I N$ & Overall \\
\hline \multirow{2}{*}{$E N$} & $.377 * *$ & $.320 * *$ & $.380 * *$ & $.470 * *$ & $.406^{* *}$ & $.327 * *$ & $.357 * *$ & $.527 * *$ \\
\hline & $(.000)$ & $(.000)$ & $(.000)$ & $(.000)$ & $(.000)$ & $(.000)$ & $(.000)$ & $(.000)$ \\
\hline \multirow{2}{*}{$A G$} & $.353 * *$ & $.238 * *$ & $.284 * *$ & $.290 * *$ & $.428 * *$ & .060 & $.253 * *$ & $.382 * *$ \\
\hline & $(.000)$ & $(.000)$ & $(.000)$ & $(.000)$ & $(.000)$ & $(.228)$ & $(.000)$ & $(.000)$ \\
\hline \multirow{2}{*}{$\mathrm{CO}$} & $.419 * *$ & $.317 * *$ & $.386^{* *}$ & $.359 * *$ & $.378 * *$ & $.232 * *$ & $.338 * *$ & $.487 * *$ \\
\hline & $(.000)$ & $(.000)$ & $(.000)$ & $(.000)$ & $(.000)$ & $(.000)$ & $(.000)$ & $(.000)$ \\
\hline \multirow{2}{*}{$N M$} & $.296 * *$ & $.143 * *$ & $.155^{* *}$ & $.210 * *$ & $.418 * *$ & -.009 & $.190 * *$ & $.283 * *$ \\
\hline & $(.000)$ & $(.004)$ & $(.002)$ & $(.000)$ & $(.000)$ & (.855) & $(.000)$ & $(.000)$ \\
\hline \multirow{2}{*}{$O P$} & $.346^{* *}$ & $.234 * *$ & $.265 * *$ & $.330 * *$ & $.391 * *$ & $.130 * *$ & $.295 * *$ & $.400 * *$ \\
\hline & $(.000)$ & $(.000)$ & $(.000)$ & $(.000)$ & $(.000)$ & (.009) & $(.000)$ & $(.000)$ \\
\hline \multirow{2}{*}{ Overall } & $.515 * *$ & $.356 * *$ & $.418 * *$ & $.476 * *$ & $.591 * *$ & $.204 * *$ & $.409 * *$ & $.596 * *$ \\
\hline & $(.000)$ & (.000) & $(.000)$ & $(.000)$ & $(.000)$ & $(.000)$ & $(.000)$ & $(.000)$ \\
\hline
\end{tabular}

Legend:

$$
\begin{aligned}
& E N=\text { Extraversion } \\
& A G=\text { Agreeableness } \\
& C O=\text { Conscientiousness } \\
& N M=\text { Neuroticism } \\
& O P=\text { Openness } \\
& C C=\text { Crime Control }
\end{aligned}
$$

$S E=$ Service
$T R=$ Traditionalism
$R C=$ Receptive to Change
$C Y=$ Cynism
$S O=$ Solidarity
$I N=$ Isolation

SE $=$ Service

$I N=$ Isolation

\subsection{Significance on the Relationship between Personality and Perceptions of Police Subculture among Philippine National Police Personnel}

Table 5.3 show the value of correlation coefficient, $r=0.596$ and the P-value that was less than 0.05 when the level of personality was correlated with the perception of police subculture among Philippine National Police personnel. The implication that there is no important association between personality and the perception of police subculture among police personnel was therefore rejected. The more positive the personality is, the more likely the police personnel had high perceptions of police subculture.
Distinctively, the result revealed that all indicators of personality were positively correlated with the perception of police subculture among Philippine National Police personnel, since the registered p-value was less than 0.05 and $r=$ value which is equal to 0.527 on extraversion, 0.382 on agreeableness, 0.487 on conscientiousness, 0.283 on neuroticism, 0.400 on openness. Data showed the positive association of the two variables.

Furthermore, data showed that all indicators of perception of police subculture were positively correlated with personality, since the registered p-value is less than 0.05 and $\mathrm{r}$-value which is equal to 0.515 for crime control, 
0.356 for service, 0.418 for traditionalism, 0.476 for receptive to change, 0.591 for cynism, 0.204 for solidarity and 0.409 for isolation. Hence the two variables were positively associated.

\subsection{Significance on the Influence of the Exogenous Variables on the Perceptions of Police Subculture among Philippine National Police Personnel}

With the use of regression, the researcher examined if there were possible influence relationships. When perception of police subculture among police personnel was regressed on the police stress, multifactor leadership and personality, it generated an $\mathrm{R}^{2}$ of .481 as shown on Table 6 . The ANNOVA value of this regression was 122.355 , significant at .000 . it can be stated therefor that the combination of the three exogenous variables significantly influenced perception of police subculture. The $\mathrm{R}^{2}$ of .481 indicated that $48.1 \%$ of the variance in perception of police subculture was attributed to police stress, multifactor leadership and personality. This meant further that $51.9 \%$ of the variation in perception of police subculture was attributed to other variables not covered in this study. Examining further, the table showed that among the three exogenous variables, personality had the greatest contribution $($ Beta $=.404$, P-value $=.000)$ followed by multifactor leadership with $($ Beta $=.262, \mathrm{P}$-value $=.000)$ and the lowest was police stress of police stress with ( Beta $=.118, \mathrm{P}$-value $=.000)$. Hence, all of the three variables significantly influenced perception of police subculture among Philippine National Police personnel.

\subsection{Establishing the Best Structural Model for Perceptions of Police Subculture}

This section highlights the analysis on the interrelationships among police stress, multifactor leadership, and personality to perception of police subculture. There are four alternative models tested to achieve the best fit model of perception of police subculture among Philippine National Police personnel. Each model has a structure that could be broken down into two sub-models that are a measurement model and a structural model. The measurement model represents the measures loads on each factor to their latent constructs while the structural model defines relations among the latent variables. Moreover, the assessment of fit was used as baseline for accepting and rejecting the model.

In general, the investigator sets the correlation between the causal relationships of the latent variable and the various latent variables to the different latent factors. Furthermore, it institutes the relationship between endogenous and exogenous variables. The moment that structured model exhibits with suitable fit, it underscores that there is consistency of the empirical relationships among variables inferred by the model. The model parameter estimates entail the magnitude and direction of the relationships among variables.

\subsection{Direct and Indirect Effect}

There were five hypothesized (Conceptual) Models formulated and tested in this study. Screening of variables was critically observed to give premium on the normality of the data. Variables with interval or ratio data were counted in the formulation of models. Generated models of this study were solidified with theories. The indirect effects are relationships between predictor variable and dependent variables which are mediated by passing through one or more variables in between. The magnitude of the indirect effects is determined by cross multiplying the coefficients for any path combinations which connects the predictor variable on the left side with a dependent variable on the right side and eventually summing up to get its total. The total effect of a certain predictor variable on a dependent variable is the sum of its direct and indirect effect.

\subsection{Generated Model 1}

The generated structural model 1 is exhibited in Figure 7. It could be viewed in Table 7 emphasizing the direct effects of predictor variables to the dependent variable which is the perception of police subculture among the Philippine National Police Personnel. Personality has the highest total effect of .600 on perception of police subculture. This followed by multifactor leadership with .386 effects and efficacy belief respectively with .219 effects on the perception of police subculture.

Table 8 articulates the effects among latent variables and between measured and latent variables were estimated to produce regression weights. Results showed that personality and multifactor leadership are latent variables which significantly predict the endogenous variable, perception of police subculture $(p<0.05)$. It can be also seen that the factor inspirational motivation highly represents the latent variable, multifactor leadership $($ Beta $>0.080, \mathrm{p}<0.05)$.

Revealed in Table 9 is the examination of Model 1 using goodness of fit indices: Chi-square/Degrees of Freedom (CMIN/DF), Root Mean Square of Error Approximation (RMSEA, Normed Fit Index (NFI),TuckerLewis Index (TLI) Comparative Fit Index(CFI) and Goodness of Fit Index (GFI). The criterion for each Index that indicates a good fit is also shown in Table 11. The result of the goodness fit of the model is poor because RMSEA (.111) is not less than .05 and p-close (.000) is not greater than .05 . the rest of the indices like NFL< TLI, CFI and GFI conformed the model fit value but still the model remains poor because there are some requirements in the 
measurement of goodness of fit which are not met or satisfied.

\subsection{Generated Model 2}

Presented in Figure 8 is the generated structural model 2 showing the interrelationship between exogenous variables: police stress, multifactor leadership, personality and its causal relationship on perception of police subculture.
It could be observed in Table 10 that the direct effects of predictor variables to be dependent variable which is the perception of police subculture among Philippine National Police Personnel pointed out that personality has the highest total effects .611 on perception of police subculture. While police stress has total effect .234 and multifactor leadership has total effect of .189 on perception of police subculture.

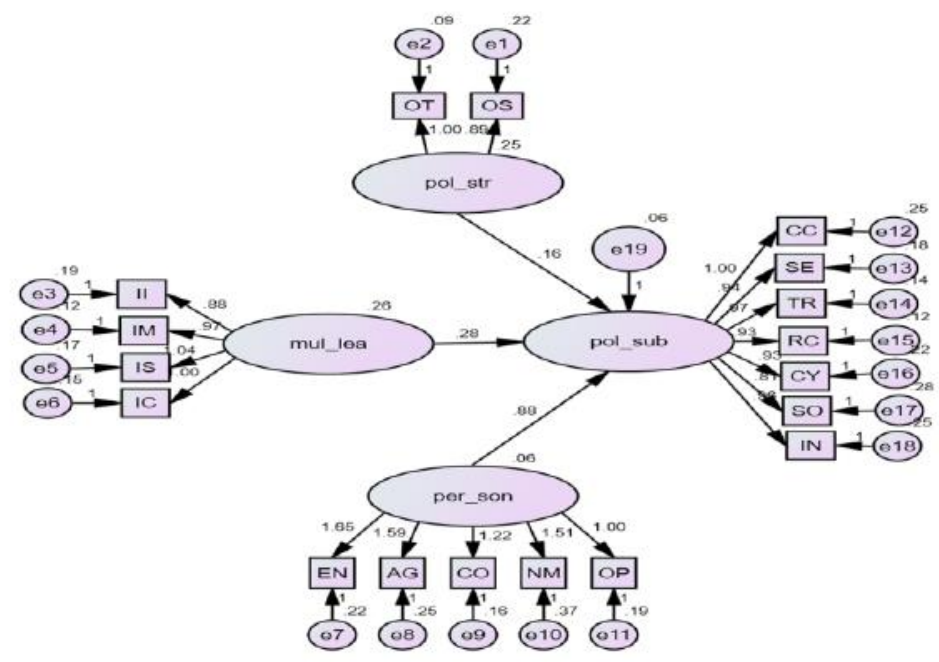

Fig.7. Generated Model 1 Showing Direct Casual Relationship of Police Stress, Multifactor Leadership, Personality traits and Perceptions of Police Subculture

Legend:

Pol str- Police Stress

OT- operational stress

OS-organizational Stress

Mul_lea-Multifactor leadership

II- idealized influence

IM-inspiration motivation CO-conscientiousness
IS- intellectual stimulation
NM-neuroticism
SO- solidarity
IC- individual consideration
OP-openness
IN-isolation
per_son-personality
pol_sub-police subculture
EN-extraversion
CC-Crime control
SE-service

TR- traditionalism

Table 7 Direct and Indirect Effects of the Independent Variables on Perceptions of Police Subculture of Model 1

\begin{tabular}{llll}
\hline Variables & Direct Effect & Indirect Effect & Total Effect \\
\hline Police Stress & .219 & - & .219 \\
Multifactor Leadership & .386 & - & .386 \\
Personality & .600 & - & .600 \\
\hline
\end{tabular}

Table 8

Estimates of Variable Regression Weights in Generated Model 1 


\begin{tabular}{|c|c|c|c|c|c|c|c|}
\hline & & & Estimate & S.E. & Beta & C.R. & P-value \\
\hline pol_sub & <--- & mul_lea & .276 & .041 & .386 & 6.686 & $* * *$ \\
\hline pol_sub & $<---$ & per_son & .881 & .134 & .600 & 6.570 & $* * *$ \\
\hline pol_sub & $<---$ & pol_str & .158 & .049 & .219 & 3.246 & .001 \\
\hline$O T$ & $<---$ & pol_str & 1.000 & & .864 & & \\
\hline$O S$ & $<--$ & pol_str & .885 & .224 & .687 & 3.947 & $* * *$ \\
\hline$I C$ & $<---$ & mul_lea & 1.000 & & .791 & & \\
\hline$I S$ & $<---$ & mul_lea & 1.036 & .065 & .784 & 15.852 & $* * *$ \\
\hline$I M$ & $<--$ & mul_lea & .969 & .058 & .823 & 16.588 & $* * *$ \\
\hline II & $<--$ & mul_lea & .882 & .061 & .720 & 14.434 & $* * *$ \\
\hline$C C$ & $<--$ & pol_sub & 1.000 & & .591 & & \\
\hline$S E$ & $<--$ & pol_sub & .939 & .098 & .623 & 9.598 & $* * *$ \\
\hline$T R$ & $<--$ & pol_sub & .968 & .094 & .687 & 10.247 & $* * *$ \\
\hline$R C$ & $<---$ & pol_sub & .929 & .090 & .693 & 10.302 & $* * *$ \\
\hline$C Y$ & $<---$ & pol_sub & .933 & .102 & .582 & 9.136 & $* * *$ \\
\hline SO & $<--$ & pol_sub & .808 & .102 & .481 & 7.897 & $* * *$ \\
\hline$I N$ & $<--$ & pol_sub & .956 & .106 & .573 & 9.041 & $* * *$ \\
\hline$O P$ & $<--$ & per_son & 1.000 & & .495 & & \\
\hline$N M$ & $<--$ & per_son & 1.513 & .215 & .523 & 7.027 & $* * *$ \\
\hline$C O$ & $<--$ & per_son & 1.224 & .161 & .607 & 7.613 & $* * *$ \\
\hline$A G$ & $<--$ & per_son & 1.587 & .207 & .616 & 7.664 & $* * *$ \\
\hline$E N$ & $<--$ & per_son & 1.649 & .210 & .654 & 7.870 & $* * *$ \\
\hline
\end{tabular}

Legend:

$\mathrm{CC}=$ Crime Control

$\mathrm{SE}=$ Service

$\mathrm{TR}=$ Traditionalism

$\mathrm{RC}=$ Receptive to Change

$\mathrm{CY}=$ Cynism

$\mathrm{SO}=$ Solidarity

IN= Isolation
OS=Operational Stress

OT $=$ Organizational Stress

pol_str $=$ Police Stress

II = Idealized Influence

$\mathrm{IM}=$ Inspirational Motivation

IS = IntellectualStimulation

IC = Individualized Consideration mul_lea $=$ Multifactor Leadership

$\mathrm{EN}=$ Extraversion

$\mathrm{AG}=$ Agreeableness

$\mathrm{CO}=$ Conscientiousness

$\mathrm{NM}=$ Neuroticism

$\mathrm{OP}=$ Openness

per_son Personality

pol_sub $=$ Police Subculture

Table 11 Estimates of Variable Regression Weights in Generated Model 2

\begin{tabular}{llllcccc}
\hline & & & Estimate & S.E. & Beta & C.R. & P-value \\
\hline pol_sub & $<---$ & mul_lea & .149 & .055 & .189 & 2.716 & .007 \\
pol_sub & $<---$ & per_son & .944 & .153 & .611 & 6.178 & $* * *$ \\
pol_sub & $<---$ & pol_str & .185 & .049 & .234 & 3.802 & $* * *$ \\
OT & $<---$ & pol_str & 1.000 & & .843 & & \\
OS & $<---$ & pol_str & .930 & .163 & .704 & 5.701 & $* * *$
\end{tabular}




\begin{tabular}{llllllll} 
IC & $<---$ & mul_lea & 1.000 & & .785 & & \\
IS & $<---$ & mul_lea & 1.032 & .067 & .775 & 15.405 & $* * *$ \\
IM & $<---$ & mul_lea & .951 & .060 & .802 & 15.932 & $* * *$ \\
II & $<---$ & mul_lea & .871 & .063 & .701 & 13.852 & $* * *$ \\
CC & $<--$ & pol_sub & 1.000 & & .616 & & \\
SE & $<---$ & pol_sub & .943 & .090 & .651 & 10.461 & $* * *$ \\
TR & $<---$ & pol_sub & .973 & .087 & .713 & 11.179 & $* * *$ \\
RC & $<---$ & pol_sub & .934 & .083 & .719 & 11.245 & $* * *$ \\
CY & $<---$ & pol_sub & .932 & .094 & .606 & 9.914 & $* * *$ \\
SO & $<---$ & pol_sub & .817 & .094 & .512 & 8.655 & $* * *$ \\
IN & $<---$ & pol_sub & .960 & .097 & .601 & 9.847 & $* * *$ \\
OP & $<---$ & per_son & 1.000 & & .503 & & \\
NM & $<--$ & per_son & 1.142 & .186 & .401 & 6.139 & $* * *$ \\
CO & $<--$ & per_son & 1.247 & .153 & .630 & 8.157 & $* * *$ \\
AG & $<---$ & per_son & 1.385 & .183 & .546 & 7.546 & $* * *$ \\
EN & $<---$ & per_son & 1.829 & .210 & .738 & 8.726 & $* * *$ \\
\hline
\end{tabular}

Regression weights were estimated to determine the effects between measured and latent variables. As shown in Table 11, exogenous latent variable, police stress and personality significantly predict the endogenous variable, perception of police subculture. These are noticeable with their beta values of .611 and .234 with pvalues less than .05 level of significance. The latent variable efficacy belief was found to be reasonable representative of measured variable inspirational motivation, highly represents the latent variable, multifactor leadership (Beta $>0.08, \mathrm{p}, 0.05$ ).

Regression weights in generated model 4 were estimated to determine the effects between measured and latent variables, multifactor leadership and personality. As shown in Table 17, exogenous latent variable personality significantly predict the endogenous variable, perception of police subculture. There is noticeable beta value of .669 with $\mathrm{p}$-value less than .05 level of significance. The latent variable multifactor leadership was found to be reasonable representative of measured variable inspirational motivation (Beta $=.814, \mathrm{p}<0.05$ ). Presenting the goodness of fit measures to evaluate the data of model 4 is demonstrated in Table 18. For instance, indices CMIN/DF was 5.132, NFI was .814, TLI was .814, CFI was .843 , and GFI was .850 , respectively emphasizing a logical fit for data. Nevertheless, the remaining indices which are RMSEA (.102) and p-close (.000) deviate the appropriate values for acceptance. Therefore, generated model 4 is a poor fit model.

Table 17 Goodness of Fit Measures of Structural Model 4

\begin{tabular}{ccc}
\hline INDEX & CRITERION & MODEL FIT VALUE \\
P-Close & $>0.05$ & .000 \\
CMIN/DF & $0<$ value $<2$ & 5.132 \\
GFI & $>0.95$ & .850
\end{tabular}


CFI

$N F I$

$T L I$

RMSEA
$>0.95$

$>0.95$

.814

$>0.95$

.814

$<0.05$

Legend:

$\begin{array}{lll}\text { CMIN/DF } & - & \text { Chi-Square/Degrees of Freedom } \\ \text { NFI } & - & \text { Normed Fit Index } \\ \text { TLI } & - & \text { Tucker Lewis Index } \\ \text { CFI } & - & \text { Comparative Fit Index } \\ \text { GFI } & - & \text { Goodness of Fit Index } \\ \text { RMSEA } & - & \text { Root Means Square of Error Approximation } \\ \text { Pclose } & - & \text { P of Close Fit }\end{array}$

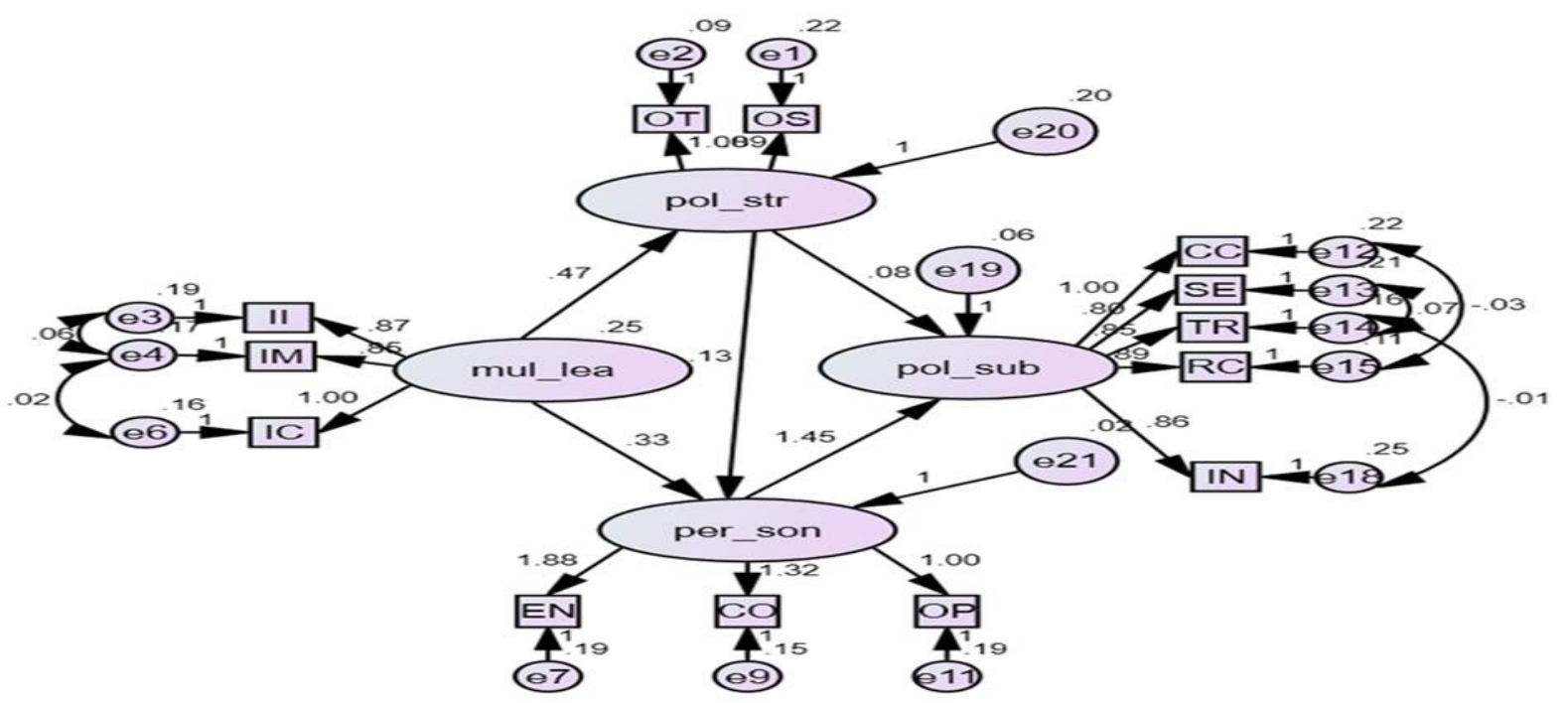

Fig. 11. The Best Fit Model for Perception of Police Subculture

\subsection{Generated Model 3}

Introduced in Figure 9 is the generated structural model 3 showing direct causal link of the variables occupational stress and their relationship to each other. It shows combined effects of perception of barriers and frustration discomfort. It could be grasped from the data that perception of barriers and frustration discomfort has negligible correlation with computed r-value of .16. 
Further, perception of barriers and frustration discomfort consistently represent their respective attributes with their Betas $>0.16$.

It could be observed in Table 10 that the direct effects of predictor variables to the dependent variable which is the occupational stress of police officers pointed out that .815 has the highest on occupational and followed by frustration discomfort with total effect of .006 on occupational stress.

Examining the goodness of fit of generated structural model 3 portrayed in Table 11. The fit indices CMIN/DF, NFI, TLI, CFI, GFI were all in the acceptable ranges indicating a good fit of the model. On the contrary, the indices RMSEA and p-values failed to meet the criteria which indicate a poor fit for the model.

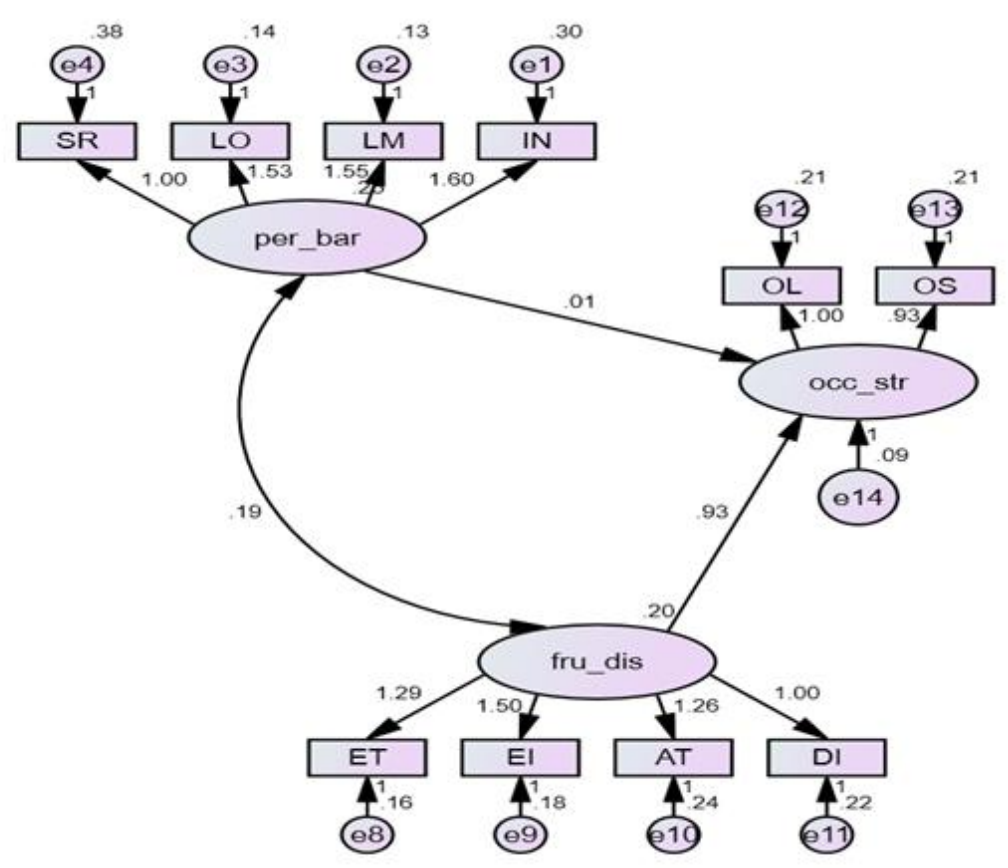

Fig.9. Generated Model 3Showing Direct Causal Link of the Variables Toward Occupational Stress and their Relationship of Each Other

\section{Legend:}

per_bar- Perception of barriers

SR- Social Depression

LO- Lack of time/opportunities

LM - Lack of Motivation

IN - Inhibition

Occ_str - Occupational Stress

OL - Operational Stressors

OS - Organizational stressors

\author{
wor_env- Work Environment \\ NT- Negative Environment \\ CS - Counseling Support \\ FS - Family Discussion with Coworkers \\ fru_dis - Frustration Discomfort \\ ET - Entitlement \\ EI - Emotional Intolerance \\ AT -Achievement \\ DI -Discomfort Frustration
}

\subsection{Generated Model 5}

The generated structural model 5 in standardized solution is included in Figure 11. Results denote that the latent variables police stress representing the measured variables organizational stress and operational stress: multifactor leadership represented by the measured variable in terms of idealized influence, inspirational motivation and individualized consideration; and 
personality represented by the measured variables in terms of extraversion, conscientious and openness has important influence to the latent variable police subculture perception. Possible to learn from the data that multi factor leadership components: idealized influence, inspirational motivation and individualized consideration bear no significant correlations to each other. Likewise, police subculture components: crime control, service, traditionalism, receptive to changes and isolation found no significant correlation to each other.
It could be viewed in Table 19 that the direct effects of predictor variables to the dependent variable, Multifactor leadership has the high total effect of .468 on perception of police subculture. Regression weights were estimated to measure the effects between measured and latent variables. Depicted in Table 20, the model proposes that personality is a predictor of police subculture as demonstrated by its beta equals .774 with p-value (.000) level of significance.

Table 19 Estimates of Variable Regression Weights in Best Fit Model

\begin{tabular}{|c|c|c|c|c|c|c|c|}
\hline & & & Estimate & S.E. & Beta & C.R. & P-value \\
\hline pol_str & $<--$ & mul_lea & .465 & .068 & .468 & 6.852 & $* * *$ \\
\hline per_son & $<--$ & mul_lea & .331 & .050 & .697 & 6.669 & $* * *$ \\
\hline per_son & $<--$ & pol_str & .129 & .036 & .269 & 3.547 & $* * *$ \\
\hline pol_sub & $<--$ & per_son & 1.449 & .212 & .774 & 6.843 & $* * *$ \\
\hline pol_sub & $<--$ & pol_str & .083 & .065 & .093 & 1.279 & .201 \\
\hline$O T$ & $<--$ & pol_str & 1.000 & & .861 & & \\
\hline$O S$ & $<--$ & pol_str & .893 & .097 & .690 & 9.237 & $* * *$ \\
\hline$I C$ & $<--$ & mul_lea & 1.000 & & .785 & & \\
\hline$I M$ & $<--$ & mul_lea & .849 & .070 & .715 & 12.149 & $* * *$ \\
\hline$I I$ & $<--$ & mul_lea & .873 & .077 & .707 & 11.373 & $* * *$ \\
\hline$C C$ & $<--$ & pol_sub & 1.000 & & .692 & & \\
\hline$S E$ & $<--$ & pol_sub & .796 & .078 & .614 & 10.253 & $* * *$ \\
\hline$T R$ & $<--$ & pol_sub & .851 & .076 & .694 & 11.189 & $* * *$ \\
\hline$R C$ & $<--$ & pol_sub & .891 & .075 & .763 & 11.828 & $* * *$ \\
\hline$I N$ & $<---$ & pol_sub & .864 & .085 & .608 & 10.171 & $* * *$ \\
\hline$O P$ & $<--$ & per_son & 1.000 & & .479 & & \\
\hline$C O$ & $<--$ & per_son & 1.320 & .163 & .634 & 8.094 & $* * *$ \\
\hline$E N$ & $<--$ & per_son & 1.880 & .220 & .722 & 8.564 & $* * *$ \\
\hline
\end{tabular}

\section{Legend:}

$$
\begin{gathered}
C C=\text { Crime Control } \\
\text { SE= Service } \\
T R=\text { Traditionalism } \\
R C=\text { Receptive to Change } \\
\text { IN= Isolation } \\
\text { pol_sub = Police Subculture }
\end{gathered}
$$

$$
\begin{gathered}
\text { OS=Operational Stress } \\
\text { OT = Organizational Stress } \\
\text { pol_str = Police Stress } \\
I I=\text { Idealized Influence } \\
I M=\text { Inspirational Motivation } \\
I C=\text { Individualized Consideration }
\end{gathered}
$$

mul_lea= Multifactor Leadership

$$
\begin{gathered}
\text { EN = Extraversion } \\
C O=\text { Conscientiousness } \\
O P=\text { Openness }
\end{gathered}
$$$$
\text { per_son Personality }
$$

\section{Table 20}

Goodness of Fit Measures in the Best Fit Model 


\begin{tabular}{|c|c|c|}
\hline INDEX & CRITERION & MODEL FIT VALUE \\
\hline P-Close & $>0.05$ & .998 \\
\hline CMIN/DF & $0<$ value $<2$ & 1.157 \\
\hline GFI & $>0.95$ & .976 \\
\hline CFI & $>0.95$ & .995 \\
\hline NFI & $>0.95$ & .968 \\
\hline TLI & $>0.95$ & .994 \\
\hline RMSEA & $<0.05$ & .020 \\
\hline
\end{tabular}

\section{Legend:}

$\begin{array}{lll}\text { CMIN/DF } & - & \text { Chi-Square/Degrees of Freedom } \\ \text { NFI } & - & \text { Normed Fit Index } \\ \text { TLI } & - & \text { Tucker Lewis Index } \\ \text { CFI } & - & \text { Comparative Fit Index } \\ \text { GFI } & - & \text { Goodness of Fit Index } \\ \text { RMSEA } & - & \text { Root Means Square of Error Approximation } \\ \text { P close } & - & \text { P of Close Fit }\end{array}$

Distinguishing the best fit model, all the indices included must consistently fall within acceptable ranges. Chi-square/degrees of freedom value should be less than 5 with its corresponding p-value greater or equal to 0.05 . Root Mean Square of Error Approximation value must be below 0.05 and its corresponding p-close value must be greater or equal to 0.05 . The other indices such a Normed Fit Index, Tucker Lewis Index, Comparative Fit Index and Goodness of Fit must be all greater than 0.90 .

Table 21 Summary of Goodness of Fit Measures of the Five Generated Models

\begin{tabular}{|c|c|c|c|c|c|c|c|c|}
\hline Model & $\begin{array}{l}P \text {-value } \\
(>0.05)\end{array}$ & $\begin{array}{l}C M I N / D F \\
(0<\text { value }<2)\end{array}$ & $\begin{array}{l}\text { GFI } \\
(>0.95)\end{array}$ & $\begin{array}{l}\text { CFI } \\
(>0.95)\end{array}$ & $\begin{array}{l}\text { NFI } \\
(>0.95)\end{array}$ & $\begin{array}{l}T L I \\
(>0.95)\end{array}$ & $\begin{array}{l}\text { RMSEA } \\
(<0.05)\end{array}$ & $\begin{array}{l}\text { P-close } \\
(>0.05)\end{array}$ \\
\hline 1 & .000 & 5.957 & .819 & .780 & .748 & .745 & .111 & .000 \\
\hline 2 & .000 & 5.061 & .838 & .822 & .789 & .791 & .101 & .000 \\
\hline
\end{tabular}




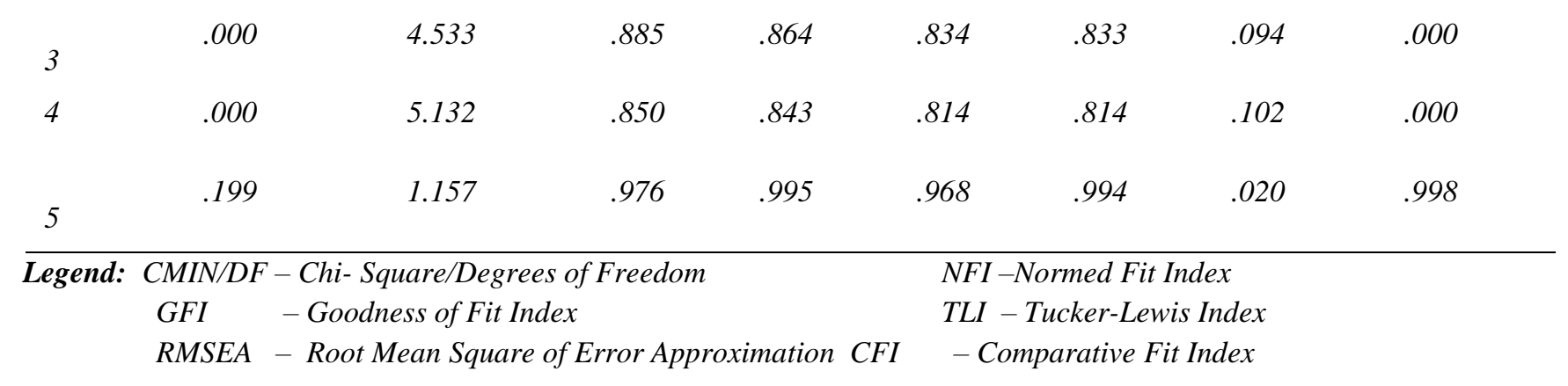

The first generated structural model showed the direct causal relationship of the exogenous variables, police stress, multifactor leadership, and personality to endogenous variable, perception of police subculture. Some of the computed indices of this model do not reach the acceptable ranges of values, thus, the model is a poor fit.

The second generated structural model exhibits the interrelationship of the exogenous variables: polices stress, multifactor leadership, personality and its causal relationship on the endogenous variable, perception to police subculture. This model found poor fit because the $\mathrm{p}$ value $=0.000$ and $\mathrm{RMSEA}=0.101$ with $\mathrm{p}$-close $=0.000$, all did not fall to the acceptable ranges of values.

The third generated structural model highlights the direct causal link of the variables toward perceptions of police subculture and their relationships for each other. The results settled to non-fit model as indicated by its $\mathrm{p}$ value $=.000$ and $\mathrm{RMSEA}=0.094$ with $\mathrm{p}$-close $=0.000$.

The fourth generated structural model showed another direct causal link of the variables toward perception of police subculture and their relationships for each other. The results settled to non-fit model as indicated by its $\mathrm{p}$-value $=.000$ and $\mathrm{RMSEA}=0.102$ with $\mathrm{p}$-close $=$ 0.000 .

Furthermore, the modified model showing the direct causal link of the exogenous variables, multifactor leadership toward the endogenous variable, perception of police subculture and their relationship with each other. The generated model 5 found to have indices that shows a very good fit to the data as indicated by $\mathrm{CMIN} / \mathrm{DF}=1.157$, $\mathrm{p}$-value $=0.199$, RMSEA $=0.020, \mathrm{p}$-close $=0.998$ and indices such as NFI (0.968), TLI(0.994), CFI(0.995) and GFI(0.976). All of the indices with their corresponding values were greater than 0.90 or meet the requirements of goodness of fit measures. Since, generated model 5 is a good fit model of job satisfaction, this does not warrant for further testing to any models. It is therefore stated that the null hypothesis is rejected. It could be surmised that there is model that best fit on perception on police subculture among Philippine National Police personnel.

The framework clearly illustrates the multifactor leadership edifice as predictors of police subculture experience. Consequently, multifactor leadership is the most important ingredient of moral providers in reference of police subculture. Thus, the findings carry over police subculture as the bedrock of multifactor leadership in terms of Idealized influence, Inspirational motivation and individualized consideration ; and with reference to police stress in terms of organizational stress and operational stress and also with reference of personality in terms of extraversion, conscientious and openness.

\subsection{The Level of Police Stress of the Philippine National Police Personnel}

The high level rating of police stress among police personnel is an indication that stress is oftentimes manifested and they are highly susceptible to stress in terms of operational and organizational activities. In addition, the findings is allied to the viewpoint of Dempsey, Forst, and Carter (2019) which states police officer protect people, which tend to be unacceptable to the police; and the persistent knowledge of the risk of being legally responsible for actions carried out while in service. Additionally, finding is also similar to the idea of Scott (2004) which stated that organizational stress was the most stressful problem among police officers and particularly their perceptions on administrative changes in the police organizational setting. Moreover, the overall findings is consonance the statement of (Anshel, 2000) Police work is considered to be one of the most stressful job and as police officers susceptible to trauma and stress.

\subsection{The Level of Multifactor Leadership among Philippine National Police Personnel}

The overall high level rating of multifactor leadership among police is an indication that that leadership of police personnel is oftentimes manifested and they are highly able to manage problems in the work place. The findings is supported the study of Dempsey, Forst and Carter (2016) police officers have often been educated in standard 
policies or leadership practices, or overlook that their activities can build a highly stressful atmosphere and affect the health and well-being of a living system or organization through current management and administrative courses. In addition, the findings in terms of idealized influence among police personnel is parallel to the idea of Northouse (2016) stated that police officers have very high moral and ethical standards of behaviour, and usually do the correct thing when faced with moral and ethical decisions, and subordinates have a great respect for these police leaders and generally have a high level of trust.

\subsection{The Level of Personality of the Philippine National Police Personnel}

The overall high level rating of personality traits among police personnel is indication that personality is oftentimes manifested and they are highly confortable in working with community and concern of people safety. In addition, the findings supported the study of Burger (2019) stated that police officers with high levels of personality traits appear to get more anxious about daily stressors than those with low levels of stress and are more prone to high levels of anxiety. In addition, police officers with high levels of personality traits appear to get more anxious about daily stressors than those with low levels of stress and are more prone to high levels of anxiety ( Chow \& Roberts, 2014; Kotov, Gamez, Schmidt, \& Watson, 2010: Lahey, 2009).

\subsection{The Level of Perception of Police Subculture among Philippine National Police Personnel in Zamboanga City}

The overall high level rating of police subculture among Philippine National Police personnel is indication that subculture is oftentimes manifested and they are highly aggressive in crime control, public service and peace and order. In addition, the findings is parallel to the declaration of Crank and Caldero (2000); Sherman (1982) stated that police personnel with high subcultures supports a distinctive system of values, with particular emphasis on integrity, courage and freedom. Furthermore, in certain cases the abuse of power and the infringement of the fundamental rights (Kappeler, Sluder, and Alpert, 1998; Skolnick \& Fyfe, 1993; Fitch, 2014). In addition, crime prevention is given top priorities and viewed as the real police work in the police culture, while other police duties such as peace management and community work are regarded primary or even a waste of energy (Klockars, 1985; Paoline, 2003; Paoline, Myers, \& Worden, 2000; Rumbaut \& Egon, 1979; Sparrow et al., 1990; Walker \& Katz, 2005; Westley, 1970; Wilson, 1968).
4.18 Regression Analysis on the Influence of Police Stress, Multifactor Leadership and Personality to Police Subculture

In the singular capacities of the independent variables, it showed that only multifactor leadership and personality influence greatly on dependent variable. The three predictor variables require one another to affect the dependent variable substantially. The findings of Lasiewicki (2007), Cooper \& Sawaf, (1998); Scott, (2003); Whisenhand \& Ferguson, (2002) which stated that leadership influence police subculture in a way that police personnel's behaviour depends on the leadership capabilities and influence of the police supervisor. Leadership positively influence on most aspects of police subculture. In that sense, multifactor leadership has been empirically found to be positively associated with police subculture.

\subsection{Best Fit Model for Police Subculture}

The best fit model for police subculture perception is generated in model number 5. Model number 5 is exemplified by the influence of multifactor leadership on police stress and personality. Moreover, these independent variables also influence the police subculture perception positively. In addition, pathways from multifactor leadership to police stress to police subculture is significant. Another was also cited from multifactor leadership to personality to police subculture. The identified pathways are significant in nature. Therefore, increasing the level of multifactor leadership is also an increase the police stress and personality and will also an increase in the respondents level of perception of police subculture. On other hand, the indices resulted in the generated model number 5 are all within the acceptable range. Specifically, $\mathrm{CMIN} / \mathrm{DF}=1.157, \mathrm{p}$-value $=0.199$, RMSEA $=0.020, \mathrm{p}$-close $=0.998$ and indicessuch asNFI (0.968), TLI(0.994), CFI(0.995) and GFI(0.976)respectively.

\subsection{Conclusion}

The Structural Equation Model strengthened the consistency of the study because the analysis goes through the steps of model specification, model estimation and model evaluation. There is significant relationship of the following variables: police stress, multifactor leadership and personality with perception of police subculture consistent with the literature as underscored in correlation between measures. Of the five structural models, only Model 5 has indices which indicate an ideal fit to the details, therefore, it is identified as the best fitting structural model.

A high score level results on police stress indicates that police personnel experienced a high degree of stress in 
terms of operational and organizational activities. This result is supported by the pronouncement of (Anshel, 2000) that Police work is considered to be one of the most stressful job and susceptible to trauma and stress. On the other side, Scott (2004) still supports the findings, arguing that police officers are identifiable individuals in the public and have problems finding protection on or off work. Moreover, this result supported the theory pronounced by (Scheingold 1984 \& Pollock, 2007) which stated that police stress was one element which led to the offensive nature of police subculture.

A high score level results of multifactor leadership indicates that police officers experienced a high degree of leadership in the work place. This result supported on the theory Northouse (2016) which states that multifactor leadership (transformational leadership) police officer who employed power and authority to put evil ends and which associated to police subculture. It means that police officer with higher leadership can overcome the challenges of their working environment. Moreover, a high degree of leadership it increases awareness of police personnel regarding the importance of work outcome It promotes subordinates to be outside the ego-interest of others in their team and police organization and promotes subordinates to take good care of significantly lower-level needs (Bass, 1985; Yukl, 2013).

A high score level on personality indicates that police personnel experienced a high degree of personality are helpful and cooperative. In addition, the findings is parallel the statement of (Donnellan, Conger, \& Bryant, 2004; Jensen-Cmapbell \& Graziano, 2001; Malouff , Thorsteinson, Schutte, Bhullar, \& Rooke, 2010) which states that high on personality dimension are helpful, trusting and sympathetic. This results is supported by the pronouncement of (Donnellan, Conger, \& Bryant, 2004; Jensen-Cmapbell \& Graziano, 2001; Malouff , Thorsteinson, Schutte, Bhullar, \& Rooke, 2010) that high character has more delightful social relationships and fewer truculent dialogues than those low on this personality aspect.

On other hand, the high score level results on perception police subculture indicates that the police personnel experienced a high degree of perception of police subculture in the work place. This results is supported the study of Crank and Caldero (2000); Sherman (1982) which states that police personnel with high subcultures supports a strong value system, with special focus on corporate integrity, courage and employee freedom. On other hand, police personnel with high police subculture find oneself "the only real fighters against crime" and emphasis on crime prevention (Sparrow et al.,
1990). Moreover, this result is supported the study of Walker \& Katz (2005) that police with perception police subculture labeled themselves as crime fighter.

\subsection{Recommendations}

The investigator may suggest the following recommendations based on the research results:

On high score level rating of personality of police personnel suggest that there is room for improvement by raising it up to very high level. The results indicates that the top level management of the Philippine National Police officials should formulate policies and standards for intervention programs and strategies need to be introduced to improve and empower police personnel through extensive intervention programs and crafting possible solutions for leadership of personnel.

The high score level results of police stress, police subculture and multifactor leadership in an organization police personnel suggest that there is still room for improvement by raising it to very high level. The results indicate that Philippine National Police officials should formulate policies and standards for Intervention programs that could seek to improve communication skills and provide technical expertise that partly linked to sound decision-making and the performance of responsibilities in a skilled way. However, improving integrity, caring, work ethic, social values, stress management, fairness and flexibility should be more difficult of police personnel and crafting possible solutions by pushing up into a very high level of police stress management, leadership and police subculture.

The significant relationship of the three exogenous variables: police stress, multifactor leadership, and personality with police subculture indicates that may be given focus by top level management of the Philippine National Police because higher the level of these exogenous variables high level of perception police subculture in an organization. This can be done by setting good intervention programs for improving a good perception police subculture in the workplace driven to uphold a better coping police stress, leadership and personality while developing a good relationship may it be intimate or not among members of the community and organization and continuously develop a good perception police subculture to any police activities.

The best-fit model showing multifactor leadership and personality are the strong predictors of perception of police subculture in police organization should be given a prime focus of the top-level management in the improvement of perception police subculture strategies compared to other variables above mentioned. This can be done by building a strong professional quality of life and 
keep police personnel emotionally and physically connected towards the community and members of police organization.

\section{REFERENCES}

[1] Aamodt, M., Brewster, J., Raynes, B. (1998). Is the" Police Personality" Predisposed To Domestic Violence?

[2] Aamodt, M. G., \& Kimbrough, W. W. (1985). Personality differences between police and fire applicants . Journal of Police and Criminal Psychology, 1(1), 10-13.

[3] Adler, F. Mueller, G. O. W. \& Laufer, W. S. (1994). Criminal justice. New York:

McGraw-Hill.

[4] Allen T. (2012). Testimony before the US House of Representatives, Committee on Homeland Security, Subcommittee on Oversight, Investigations, and Management.

[5] Altemeyer, B. (1998). The other authoritarian personality. Advamce in Experimental Social Psychology, 48-92.

[6] Anderson, G.S., Litzenberger, R. \& Plecas, D. (2002). Physical evidence of police officer stress. Policing: An International Journal of Police Strategies Management, 25(2), 399-420.

[7] Anshel, M. H. (2000). A conceptual model and implications for coping with stressful events in police work. Criminal Justice and Behavior, 27(3), 375.

[8] Antonakis, J. (2012). Transformational and Charismatic Leadership ( $2^{\text {nd }}$ Edtion).

[9] Atwater, L. E., Camobreco, J. F., Dionne, S. D., Avolio, B. J., \& Lau, A. N. (1997). Effects of rewards and punishments on leader charisma, leader effectiveness and follower reactions. The Leadership Quarterly, 8(2), 133-152. https://doi.org/10.1016/S1048-9843(97)900138

[10] Aydogdu,S. \& Asikgil, B. (2011). An Empirical Study of the Relationship Among Job Satisfaction, Organizational Commitment and Turnover Intention. International Review of Management and Marketing, 1(3), 43-53.

[11] American Psychological Association (APA, 2017).

[12] Bailey, J. \& Axelrod, A. H. (2001). Leadership lesson from mount rushmore: An interview with James Mcgregor Burns. The Leadership Quarterly, 12, 113-127.

[13] Bass, B. M., \& Riggio, R. E. (2006). Transformational leadership (2nd ed.). Mahwah, NJ: Lawrence Erlbaum Associates.

[14] Barth-Farkas, F. Vera, A. (2016). Transformational, transactional and cooperative police leadership in theory and practice. European Police Science and Research Bulletin, 24-43.

[15] Bass, B. M. \& Avolio, B. J. (2000). MLQ Multifactor Leadership Questionnaire Redwood City: Mind Garden.
[16] Bass, B. M. \& Bass, R. (2009). The Bass handbook of leadership: Theory, research, and managerial applications. New York.

[17] Bass, B. (1990). Bass and stodgill's handbook of leadership: Theory, research,and managerial applications (3rd ed.). New York: The Free Press.

[18] Bass, B. M. (1985). Leadership and performance beyond expectations. New York

[19] Bass, B. (1960). "Leadership, Psychology, and Organizational Behavior", New York, Harper

[20] Bates, M. J, Bowles, S., Hammermeister, J, Stokes, C., Pinder, E., Moore, M., Fritts, M., Vythilingam, M. , Yosick, T., Rhodes, J., Myatt, C., Westphal, R., Fautua, D., Hammer, P. , Burbelo, G. (2010). Psychological fitness. Military Medicine, 175, ,21-38.

[21] Beito, L. (1999). 'Leadership effectiveness in community policing. ' Bristol,Indiana: Wyndham Hall Pres

[22] Biggam, K. H. \& Power, G. (1996). The personality of the Scottish police officer: The issue of positive and negative affectivity. Personality and Individual Differences, $\quad 20 \quad$ (6), 661-667. https://doi.org/10.1016/0191-8869(96)00011-6

[23] Bittner, E. (1990). Aspects of Police Work, Boston: Northeastern University Press, 6-7.

[24] Bowie, N. (2000). A kantian theory of leadership. The Leadership \& Organization Development Journal 21(4):185-193

[25] Britt, T. W, Davison, J., Bliese, P. D., Castro, C. A. (2004). How leaders can influence the impact that stressors have on soldiers. Military Medicine. 169(7):541-545.

[25] Brown, M. K. (1981). Working the street: police discretion and the dilemmas of Reform. Russell Sage, New York,NY.

[26] Burger, J. M. (2019). Personality (10 ${ }^{\text {th }}$ edition). Cengage Learning.

[27] Buerger, M. E. (2007). Cynicism, police. In J. R. Greene (Ed.), The encyclopedia of police science (3rd ed.). New York: Routledge.

[28] Burns, J.M, (1978), Leadership. N.Y, Harper and Row.

[29] Carlan, P. E., \& Nored, L. S. (2008). An examination of officer stress: Should police departments implement mandatory counseling? Journal of Police and Criminal Psychology, 23(1), 8-15. doi:10.1007/s11896-008-9015$\mathrm{x}$

[30] Carrillo, R. A. (2010). Positive Safety Culture. Professional Safety, 55(5), 47-54.

[31] Charman, S., (2017). Police socialisation, identity and culture becoming blue. University of Portsmouth Portsmouth, United Kingdom

[32] Chen, Z. (2016). Measuring Police Subcultural Perceptions: A Study of Frontline Police Officers in China. DO - 10.1007/978-981-10-0096-6 
[33] Chow, P. I., \& Roberts, B. W. (2014). Examining the relationship between changes in personality and changes in depression. Journal of Research in Personality, 51, $38-46$.

[34] Clark, J. P. (1965). Isolation of the police: A comparison of the British and American situations. The Journal of Criminal Law, Criminology \& Police Science, 56(3), 307-319.

[35] Cochran, \& Bromley, (2003). The myth (?) of the police sub-culture. Policing:A n InternationalJournal of Police Strategies \& Management, 26(1), 88-117. DOI 10.1108/13639510310460314

[36] Cockcroft, T. (2016). Transformational Leadership And Police Culture: Outlining The Complex society? Retrieved from http://policing.oxfordjournals.org/

[37] Cockcroft, T. (2013). Police culture: Themes and concepts. London: Taylor \& Francis.

[38] Cohen, R. J., \& Swerlik, M. E. (1999). Psychological testing and assessment an introduction to tests and measurement (4th edition). Retrieved from https://trove.nla.gov.au/version/49152449

[39] Cohen, B. \& Chaiken, J. M. (1972). Police background and performance. Lanham, MD: Rowmam and littlefield.Committee on Law and Justice (1994).

[40] Conti, N. (2010). Weak links and warrior hearts: a framework for judging self and others in police training. Police Practice and Research 12(5): 410-423. Retrieved from: https: //www.tandfonline.com/ doi/abs/10.1080/15614263.2010.536726

[41] Cooper, R. K., \& Sawaf, A. (1998). Executive EQ: Emotional intelligence in leadership and organizations. New York, NY: Penguin.

[42] Costa, P. T., \& McCrae, R. R. (1992). Professional manual for the NEO PI-R. Odessa, FL: Psychological Assessment Resources.

[43] Crank, J. P. (2015). Understanding police culture( 2nd Edition). Retrieved from https://www.amazon.com > Understanding-Police-Culture-Second-Crank

[44] Crank, J. \& Caldero, M. (2000). Police Ethics: The Corruption of Noble Cause.Mathew Bendre and Company. http://www.andersonpublishing.com

[45] Crank, J. P. (2004). Understanding police culture, second edition (2nd edition).

[46] Cunniff, E. (2013). Leadership in large and complex organizations: Presentation to the IOM Committee on Department of Homeland Security Workforce Resilience,

[47] Decker, J. P. (2018). A study of transformational leadership practices to police officers' ob satisfaction and organizational commitment. Seton Hall University Dissertations and Thesis. Retrieved from https://scholarship.shu.edu/dissertations/2505

[48] Dempsey, J. S., Forst, L. S., \& Carter, S. B. (2019). An Introduction to Policing. Cengage Learning, Inc.
[49] Dempsey, J. S., Forst, L. S., \& Carter, S. B. (2016). An Introduction to Policing $9^{\text {th }}$ edition),

[50] Dirks, K. T. \& Ferrin, D. L. (2002). Trust in leadership: Meta-analytic findings and implications for research and practice. Journal of Applied Psychology,87(4):611

[51] Donnellan, M. B., Conger, R. D., \& Bryant, C. M. (2004). The big five and enduring marriages. Journal of Research in Personality, 38, 481-504.

[52] Douglas, W., Perez, J.,Moore, A. (2007). Police ethics a matter of character. Elsevier 225 Wynman Street, Waltham.

[53] Ellison, K. W. (2004). Stress and the police officer. Springfield: Charles C.Thomas Publisher LTD.

[54] Engel, R.S. (2001) Supervisory styles of patrol sergeants and lieutenants. Journal of Criminal Justice, 29(4), 341355.

[55] Everly, G. S. (2012). Resilient leadership: Building an organizational culture of resilience: Presentation to the IOM Committee on Department of Homeland Security Workforce Resilience.

[56] Feiler, D. C., \& Kleinbaum, A. M. (2015). Popularity, similarity, and the network extraversion bias. Psychological Science, 26, 593-603.

[57] Fitch, B. D. (2014). Law enforcement ethics: classic and contemporary issues (1st edition).

[58] Friedrich, R. J. (1980). Police use of force: Individual situations and organization. The Annual of the American Academy Political and Social Sciences, 452(1), 82-97.

[59] Fyfe, J. J. (1988).Police use deadly force : Research and reform. Justice Quarterly, 5(2), 165-202.

[60] Garner, J. H., Schade, T., Hepburn, J., \& Buchanan, J. (1995). Measuring the continuum of force used by and against the police. Crimrinal Justice Reveiew, 20(2), 146-168.

[61] Franz, V., \& Jones, D. M. (1987). Perceptions of organizational performance in suburban police departments: A critique of the military model. Journal of Police Science and Administration, 15(2), 153-161.

[62] Giblin, M. J. (2017). Leadership and management in police organizations. DOI: http://dx.doi.org/10.4135/9781483398006

[63] Gibson, A. and Villiers, P. (2007). Leading for those We Serve. London: NPIA/Home Office.

[64] Glasner, T. A. (2005). Police personality: What is it and why are they?. Journal of Police and Criminal Psychology, 20(1). DOI: 10.1007/BF02806707

[65] Goldberg, L. R. (1993). The structure of phenotypic personality traits. American Psychologist, 48, 26-34. DOI: 10.1037/0003-066X.48.1.26

[66] Golding, R., \& Savage, S. P. (2008). Leadership and performance management ( $2^{\text {nd }}$ edition). Handbook of policing. 
[67] Gordner, G. W. (2014). Police administration (8th Edition).

[68] Graves, W. (1996). Police cynicism: Causes and cures. FBI Law Enforcement Bulletin, 65(6), 16-16.

[69] Habashi, M. M., Graziano, W. G., \& Hoover, A. E. (2016). Searching for the prosocial personality: A Big Five approach to linking personality and prosocial behavior. Personality and Social Psychology Bulletin, 42, 11771192.

[70] Hampson, S. E., Edmonds, G. W., Dubanoski, J. P., Hillier, T. A., \& Glodberg, L. R. (2015). A lifespan behavioral mechanism relating childhood Conscientiousness to adult clinical health. Health Psychology, 34, 887-895.

[71] Harr, R. N. \& Morash, M. (1999). Gender, race and strategies of coping with occupational stress in policing.Justice Quarterly, 2,303-336. 10.1080/07418829900094151

[72] Herzberg, F. (1966). Work and the nature of man. Clevel and.Hogan, R. (1971). Personality characteristics of highly rated policemen. Personnel Psychology, 24, 679-686.

[73] Hogan, R., \& Kurtines, W. (1975). Personological correlates of police effectiveness. The Journal of Psychology, 91, 289-295.

[74] Hughes, T. A. (2014). "Idealized, Inspirational, and Intellectual Leaders in the Social Sector: Transformational Leadership and the Kravis Prize". Retrived from http://scholarship.claremont.edu/cmc_theses/906

[75] Jaramillo, F., Nixon, R., \& Sams, D. (2005). The effect of law enforcement stress on organizational commitment. Policing An International Journal of Police Strategies and Management, 28(2),321-336. DOI: $10.1108 / 13639510510597933$

[76] Jiao, A. Y. (2001a). Police and culture: A comparison between China and the United States. Police Quarterly, 4(2), 156-185.

[77] John, O. P., \& Srivastava, S. (1999). The Big-five trait taxonomy: History, measurement, and theoretical perspectives. Handbook of personality: Theory and research, 2, 102-138).

[78] Jensen-Campbell, L. A., \& Graziano, W. G. (2001). Agreeableness as a moderator of interpersonal conflict. Journal of Personality, 69, 323-362.

[79] Kappeler, V. E., Sluder, R., \& Alpert, G. P. (1998). Forces of deveiance: Understanding the dark side of policing. Prospect Heights II: Waveland.

[80] Kara, H.B., Sunger, E., \& Kapti, A. (2015). Police stress factors among law enforcement agencies: a comparison study of us and turkish police ". European Scientific Journal,11(4),1857 - 7881.

[81] Kaufman, S. B., Quilty, L. C., Grazioplene, R. G., Hirsh, J. B., Gray, J. R., Peterson, J. B., \& DeYoung, C. G. (2016). Openness to experience and intellect differentially predict creative achievement in the arts and sciences. Journal of Personality, 84, 248-258.

[82] Kingshott, B.\& Prinsloo, J. (2004). The universality of the "police canteen culture”. Acta Criminologica,17(1),116.

[83] Kotov, R., Gamez, W., Schmidt, F., \& Watson, D. (2010). Linking "big" personality traits to anxiety, depressive, and substance use disorders: A meta-analysis. Psychological Bulletin, 136, 768-821.

[85] Klockars, C. B. (1985). Dirty Harry Problem (From Moral Issues in Police Work). http://www.ncjrs.gov/App/publications/abstract.aspx?ID $=99031$

[86] Klockars, C. B. (1993). The legacy of conservative ideology and police. Police Forum, 3(1), 155-160.

[87] Kraska, P. B. (2007). Militarization and policing-Its relevance to 21 st century police.Policing, 1(4), 501-513.

[88] LaGrange, R. L. (1998). Policing American society (2nd edition). Chicago: Nelson-Hall.

[89] Lahey, B. B. (2009). Public health significance of neuroticism. American Psychologist, 64, 241-256.

[90] Lasiewicki, P. A. (2007). Achieving congruence between individual commitment to policing and organizational objectives in police departments (Doctoral dissertation). Available from ProQuest Dissertations and Theses database. (UMI No. 3350856)

[91] Legault, M. (2005). Preferred police leadership styles in northern British Columbia. Dissertation Abstracts International, 43(2), 455-533.

[92] Lester, D., Babcock, S. D., Cassisi, J. P., Genz, J. L., \& Butler, A. J. P. (1980). The personalities of english and american police. The Journal of Social Psychology, 111(1) 153154. https://doi.org/10.1080/00224545.1980.9924289

[93] Liberman, A. M., Best, S. R., Metzler, T. J., Fagan, J. A., Weiss, D. S. \&

[94] Marmar, C. R. (2002). Routine occupational stress and psychological distress in police. Policing: An International Journal of Police Strategies and

Management, 25(2), 421-439.

[95] Lingamneni, J. R. (1979). Resistance to change in police organizations: The diffusion paradigm. Criminal Justice Review, 4(2), 17-26.

[96] Malouff, J. M., Thorsteinsson, E. B., Schutte, N. S., Bhullar, N., \& Rooke, S. E. (2010). The Five-Factor Model of personality and relationship satisfaction of intimate partners: A meta-analysis. Journal of Research in Personality, 44, 124-127.

[97] Manning, P. K., (1997). Police work; the social organization of policing ( $2^{\text {nd }}$ edition). Prospect Heights, ILL: Waveland Press. 
[98] Mastrofski, Stephen D. 2004. "Controlling Street-level Police Discretion." The Annals of the American Academy of Political and Social Science, 593,100-118.

[99] Meyer, M.E. \& Steyn, J. 2009. Nurturing isolation in the south african police service: a comparison of male and female recruits. Policing: An International Journal of Police Strategies \& Management, 32(1), 108-127.

[100] Martin, Ritch, M.S. (2011). Police Corruption :An Analytical Look Into Police Ethics ,

[101] Mccartney, S. \& Parent, R. (2012). Ethics in law enforcement. Retrived

[102] McCreary, D. \& Thompson, M. (2006).Development of two reliable and valid measures of stressors in policing: The Operational and Organizational Police Stress Questionnaires. International Journal of Stress Management, 13(4), 494 - 518. DOI - 10.1037/10725245.13.4.494

[103] Miller, S. \& Gordon, I. (2014). Investigative Ethics for Police Detectives and Criminal

[104] Mollen, M., Baer, H., Evans, H., Lankler, R. C., \& Tyler, H. R. (1994). Commission report: Commission to investigate allegations of corruption and the anticorruption rocedures of the police department. New York: The Commission.

[105] Nijkerk, K. and Yuille, J., (1986). Police selection and training the role of psychology

[106] Newman, D. \& Rucker-Reed, M. (2004). Police stress, state-trait anxiety, and Stressors among U.S. Marshals. ournal of Criminal Justice, 32(6), 631-641. DOI: 10.1016/j.jcrimjus.2004.08.003

[107] Northouse, Peter G.(2016) Leadership: Theory and practice. Sage O'neill, M., Marks,M., and Singh, A., (2007). A sociology of crime, law and deviance of Thompson Learning, pp. 198-199

[108] Paoline, E. A. III. (2003). Taking stock: Toward a richer understanding of police culture. Journal of Criminal Justice, 31(3), 199-214. https://doi.org/10.1016/S00472352(03)00002-3

[109] Paoline, E. A. (2001). Rethinking police culture: Officers' occupational attitudes. New York: LFB Scholarly Publishing LLC.

[110] Paoline, E. A. (2003). Taking stock: Toward a richer understanding of police culture.Journal of Criminal Justice, 31(3), 199-214.

[111] Paoline, E. A., Myers, R. E., \& Worden, S. A. (2000). Police culture, individualism, and community policing: evidence from two police departments. Justice Quarterly, 17(3):575-605.

[112] Pienaar, J., \& Rothmann S. (2006). Occupational stress in the South African Police Service, SA. Journal of Industrial Psychology, 32(3), 72-78.
[113] Poole, E. D., \& Regoli, R. M. (1979). Police professionalism and cynicism. Criminal Justice and Behavior, 6(2), 201-206.

[114] Pollock, J. M. (2007). Ethical dilemmas and decisions in criminal justice ( $5^{\text {th }}$ Edition).

[115] Pollock, J. M. (2017). Ethical dilemmas and decisions in criminal justice Cengage

[116] Pollock, J. M.(2014). Ethical Dilemmas and decisions in Criminal Justice. Wadsworth,

[117] Pollock, Joycelyn M. (2017). Ethical Dilemmas and decisions in Criminal Justice (9th Edition).

[118] Pollock, J. M. (2004). Ethics In Crime And Justice , Dilemmas And Decisions . Wadsworth Publishing Company, 144-149.

[119] Reiner, R. (2010). The politics of the police (4th edition). New York

[120] Rich Martin, M.S. (2011). Police Corruption :An Analytical Look into Police Ethics Retrieved fromhttps://leb.fbi.gov > articles , featured-articles , police-corruption-an-analy..

[121] Roberg, R. R., Novak, K., \& Cordner, G. (2009). Police and society (4th edition). New York

[122] Rokeach, M., Miller, M.G. and Snyder, J.A. (1971). The value gap between the police and the policed. Journal of Social Issues, 27, 55-171.

[123] Rowe, W. G. \& Guerrero, L. (2016). Cases in Leadership. Sage Publication, 169-170.

[124] Rubinstein, J. (1973). City police. New York.

[125] Rubinstein, G., \& Strul, S. (2007). The Five Factor Model (FFM) among four groups of male and female professionals. Journal of Research in Personality, 41, 931-937.

[126] Rumbaut, R. G. \& Egon, B. (1979). Changing conceptions of the police role: A sociological review. Crime and Justice. DOI: 10.1086/449063

[127] Schafer, J. A. (2010). Effective Leaders and Leadership in Policing: Traits, Assessment, Development, and Expansion. Policing: An International Journal of Police Strategies \& Management, 33(4), 644-663. doi:10.1108/13639511011085060

[128] Scheingold, S. A. (1984). The Politics of Law and Order: Street Crime and Public Policy. New York: Longman.

[129] Schein, E. H. (2004). Organizational culture and leadership (3rd edition). San Francisco: Jossey-Bass

[130] Schein, E. H. (1992). Organizational culture and leadership: A dynamic view. San Francisco; Jossy-Bass.

[131] Scott, Y. M. (2004). Stress among rural and small-town patrol officers: a survey of pennsylvania municipal agencies police. Police Quarterly, 7(2), 237-261. DOI: $10.1177 / 1098611103258958$ 
[132] Scaramella, G. L., Cox, S. M., \& McCamey, W. P. (2011). Introduction to policing. Thousand Oaks: Sage.

[133] Selfhout, M., Burk, W., Branje, S., Denissen, J., van Aken, M., \& Meeus, W. (2010). Emerging late adolescent friendship networks and Big Five personality traits: A social network approach. Journal of Personality, 78, 509-538

[134] Shane, J. M. (2010). Organizational stressors and police performance.Journal of Criminal Justice, 38, 807-818.

[135] Sherman, L. (1982). Learning police ethics. Criminal Justice Ethics, 1(1), 10-19.

[136] Shernock, S. K. (2007). Police solidarity. In J. R. Greene (Ed.). The encyclopedia of police science, 2.

[137] Siegel, L. J. \& Senna, J.J. (2007). Essentials of Criminal Justice.

[138] Skolnick, J. H. (2008) Enduring issues of police culture and demographics, Policing and Society. An International Journal of Research and Policy, 18( 118:1), 35-45. DOI: $10.1080 / 10439460701718542$

[139] Skolnick, J. \& Fyfe, J. (1993). Above the law: Police and the excessive use of force. New York.

[140] Skolnick, J. H. (1986). Justice without trial (2nd edition). New York: Macmillan

[141] Sparrow, M. K., Moore, M. H., \& Kennedy, D. M. (1990). Beyond 911: A new era for policing. United States:Basic Book

[142] Sutin, A. R., Stephan, Y., Luchetti, M., Artese, A., Oshio, A., \& Terracciano, A. (2016). The five-factor model of personality and physical inactivity: A meta-analysis of 16 samples. Journal of Research in Personality, 63, 2228.

[143] Swanton, B. (1981). Social isolation of police: Structural determinants and remedies. Police Studies, 3(4), 14-21.

[144] Turiano, N. A., Chapman, B. P., Gruenewald, T. L., \& Mroczek, D. K. (2015). Personality and the leading behavioral contributors of mortality. Health Psychology, 34, 51-60.

[145] Terrill, W. \& Mastrofski, S. D. (2002). Situational and officer-based determination of the police coercion. Justice Quarterly, 19(2), 101-134.

[146] Terrill, W., and Reisig, M. D. (2003). Neighborhood context and police use of force. Journal of Research in Crime and Delinquency, 40(3), 291-321.

[147] Thiel, E. V. (2018). Big five personality test traits. Retrieved from https://www.123test.com , big-fivepersonality-theory

[148] Thompson, J. (2019). Advantages and disadvantages of transformational leadership. Retrieved from http://smallbusiness.chron.com/advantagesdisadvantages- transformational- leadership20979.html
[149] Treven, S., \& Potocan, V. (2005). Training programmes for stress management in small businesses. Education Training, 47(8/9), 640-652.

[150] Tyler, T. R. (1990). Why people obey the law: Procedural justice, legitimacy, and compliance. New Haven, CT.

[151] Tyler, T. R., \& Wakslak, C. (2004). Profiling and the legitimacy of the police: Procedural justice, attributions of motive, and the acceptance of social authority. Criminology, 42, 13-42

[152] Vadackumchery, J. (2001). Indian Police-2001: What Went Wrong Here? Retrived from https://books.google.com.ph $>$ books

[153] Van der Linden, D., Scholte, R. H. J., Cillessen, A. H. N., te Nijenhuis, J., \& Segers, E. (2010). Classroom ratings of likeability and popularity are related to the Big Five and the general factor of personality. Journal of Research in Personality, 44, 669- 672.

[154] Van Maanen, J. (1973). Observations on the making of policemen. Human Organization, 32(4), 407-418.

[155] Vera, A. \& Barth-Farkas, F. (2016). Transformational, transactional

[156] Vidya, N. \& Kotian, S. (2016). Life Satisfaction among Women Police Personnel. Imperial Journal of Interdisciplinary Research, 2(8). Retrieved from http://www.onlinejournal.in

[157] Villiers, P. (2003). Philosophy, Doctrine and Leadership: Some Core Values' in R. Adlam and P. Villiers Police Leadership in the Twenty First Century: Philosophy, Doctrine and Developments, Hook, Hampshire: Waterside Press.

[158] Violanti, J. M., \& Aron, F. (1994). Ranking police stressors. Psychological Reports, 75(2), 824-827.

[159] Waddington, P. A. J. (1999) Police (canteen) sub-culture: an appreciation. Br J Criminology 39(2):287-309

[160] Walker, S., \& Katz, C. (2005) The Police in America: An Introduction (5thedition). New York: McGraw-Hill.

[161] Westley, W.A. (1970). Violence and the police: A sociological study of law, custom, and morality. Cambridge, MA.

[162] Westley, W.A. (1953). Violence and the Police. A merican Journal Sociology, 59(1).

[163] Weston, S. J., Hill, P. L., Jackson, J. J. (2015). Personality traits predict the onset of disease. Social Psychological and Personality Science, 6, 309-317.

[164] Williams, R., \& Arrigo (2008). Ethics, crime and criminal justice. Pearson Education, www.lexisnexis.com/anderson/criminaljustice

[165] Wilson, J. Q. (1968). Varieties of Police Behavior: The Management of Law and Order in Eight Communities. Cambridge, MA

[166] Whisenand, P., \& Ferguson, F. (2002). The management of police organizations. Upper Saddle River, NJ: Prentice Hall. 
[167] Worden, (1995). The causes of police brutality: Theory and evidence of police use of force. Understanding and controlling police abuse of force. Washingto D. C. Police Executive Research Forum

[168] Worden,R. E. \& Catlin, S. (2002). The use of force by police. Policing misconduct. Upper Saddle River, NJ Prentice Hall,

[169] Yarmey A. D. (1990). Accuracy and confidence in duration estimates following questions containing marked and unmarked modifiers. Journal of Applied Social Psychology, 20, 1139-1149. 10.1111/j.15591816.1990.tb00396.x

[170] Yukl, G. (2013). Leadership in organization ( $8^{\text {th }}$ edition). 